\title{
Effect of supplemental concentrate during the dry period or early lactation on rumen epithelium gene and protein expression in dairy cattle during the transition period
}

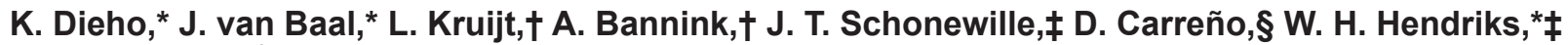 \\ and J. Dijkstra*1 \\ *Animal Nutrition Group, Wageningen University and Research, PO Box 338, $6700 \mathrm{AH}$ Wageningen, the Netherlands \\ †Animal Nutrition, Wageningen Livestock Research, Wageningen University and Research, PO Box 338, 6700 AH Wageningen, the Netherlands \\ ‡Department of Farm Animal Health, Faculty of Veterinary Medicine, Utrecht University, Yalelaan 7, 3584 CL Utrecht, the Netherlands \\ §Instituto de Ganadería de Montaña (CSIC-ULE), Finca Marzanas s/n, 24346 Grulleros, León, Spain
}

\section{ABSTRACT}

We previously reported 2 experiments with rumencannulated Holstein-Friesian dairy cows showing that during the transition period, rumen papillae surface area, and fractional absorption rate of volatile fatty acids (VFA) increase after calving. However, supplemental concentrate during the dry period and rate of increase of concentrate allowance during lactation affected papillae surface area, but not VFA absorption. Here we report the changes in gene and protein expression in rumen papillae related to tissue growth and VFA utilization. The lactation experiment treatment consisted of a rapid [RAP; $1.0 \mathrm{~kg}$ of dry matter $(\mathrm{DM}) / \mathrm{d} ; \mathrm{n}=6$ ] or gradual (GRAD; $0.25 \mathrm{~kg}$ of DM/d; $\mathrm{n}=6$ ) increase of concentrate allowance (up to $10.9 \mathrm{~kg}$ of DM/d), starting at $4 \mathrm{~d}$ postpartum (pp). The dry period experiment treatment consisted of $3.0 \mathrm{~kg}$ of $\mathrm{DM} / \mathrm{d}$ of concentrate $(\mathrm{n}=4)$ or no concentrate $(\mathrm{n}=5)$ during the last $28 \mathrm{~d}$ of the dry period. Real-time quantitative PCR analysis of rumen papillae showed that the expression of apoptosis-related genes was neither affected by day nor its interaction with treatment for both experiments. Expression of epithelial transporter genes was not affected by day or treatment in the lactation experiment, except for $N B C 1$. In the dry period experiment, expression of MCT1, NBC1, DRA, NHE2, NHE3, and $U T-B$ generally decreased after calving. A day and treatment interaction was observed for ATP1A1 in the dry period experiment, with greater expression at 18 and $8 \mathrm{~d}$ antepartum for concentrate than no concentrate. Generally, expression of VFA metabolism-related genes was not affected by day or its interaction with treatment. In the lactation experiment, immunoblot-

\footnotetext{
Received December 5, 2016.

Accepted May 8, 2017.

${ }^{1}$ Corresponding author: jan.dijkstra@wur.nl
}

ting of 5 selected genes showed that protein expression of DRA and PCCA was greater at $16 \mathrm{~d}$ pp compared with 3 and $44 \mathrm{~d}$ pp. Expression of NHE2 was greater, and that of ATP1A1 lower, at 16 and $44 \mathrm{~d}$ pp compared with $3 \mathrm{~d}$ pp, suggesting alterations in intracellular $\mathrm{pH}$ regulation and sodium homeostasis. Both MCT1 and PCCA protein were upregulated by RAP from 3 to 16 $\mathrm{d}$ pp, indicating modulations in VFA metabolism. Our data suggests that VFA absorption and metabolic capacity changed little per unit of surface area during the transition period, and suggests that a change in mitosis rate rather than apoptosis rate is associated with the increased ruminal VFA production, resulting in tissue growth. A significant but weak correlation between the examined gene and protein expression levels was observed only for PCCA, indicating that care must be taken when interpreting results obtained at either level. Key words: rumen epithelium, gene and protein expression, VFA absorption and metabolism, rumen adaptation

\section{INTRODUCTION}

Absorption of VFA by the rumen depends on several factors, including rumen fluid $\mathrm{pH}$, VFA concentration, type of VFA, and surface area of the rumen papillae (Dirksen et al., 1984; Dijkstra et al., 1993; Melo et al., 2013). Absorption occurs both through passive diffusion and protein-mediated transport (Aschenbach et al., 2011). The latter involves a range of bicarbonatedependent and bicarbonate-independent mechanisms, monocarboxylate transporters, and anion channels (Aschenbach et al., 2011). Most of the absorbed VFA are removed by the blood, with the remainder metabolized in the rumen epithelium (Bergman, 1990; Kristensen and Harmon, 2004). An increased intake of rumen fermentable OM (FOM) results in greater VFA production (Sutton et al., 2003; France and Dijkstra, 
2005) and stimulates enlargement of the ruminal absorptive area and concomitantly the capacity for VFA absorption (Dirksen et al., 1984; Melo et al., 2013; Schären et al., 2016). This coordinated response of the rumen epithelia, including adaptation on the molecular level, allows maintenance of its normal function and of intraruminal conditions within physiological boundaries (Penner et al., 2011; Bannink et al., 2012; Steele et al., 2015).

Upregulation of transporter genes associated with a higher plane of nutrition has been reported in ruminants (Yang et al., 2012; Metzler-Zebeli et al., 2013; Yan et al., 2014); likewise, during the transition period, changes in expression of some genes associated with VFA transport, metabolism, and tissue proliferation have been observed (Minuti et al., 2015; Steele et al., 2015). However, using high grain or concentrate challenge models with adult cows, Penner et al. (2009) and Steele et al. (2012) generally did not observe upregulation of transporter genes. Unfortunately, only a few of these studies coincided with in vivo measurements on VFA absorption (Penner et al., 2009) or papillae surface area (Metzler-Zebeli et al., 2013), and, consequently, any relationships between gene expression and functional changes (the capacity for VFA absorption and metabolism) remain largely unknown. Moreover, few studies report changes in expression at the protein level in lieu of expression at mRNA level (Penner et al., 2009; Metzler-Zebeli et al., 2013; Minuti et al., 2015), further limiting functional interpretation of results. Thus, an integrated set of observations on changes in rumen morphology and function, and associated changes in gene and protein expression, in response to nutrition are still lacking.

We recently reported results of 2 experiments (Dieho et al., 2016a, 2017) showing that the large postpartum increase in daily FOM intake, and thus VFA production, in dairy cattle after calving coincided with an increase in rumen papillae surface area and fractional VFA absorption rate $\left(\boldsymbol{k}_{\mathrm{a}} \mathbf{V F A}\right.$; Dieho et al., 2016b, 2017). Moreover, papillae surface area increased when feeding supplemental concentrate during the dry period compared with nonsupplemented cows (Dieho et al., 2017), and increased faster when increasing the daily concentrate allowance postpartum (pp) at a rapid compared with at a gradual rate (Dieho et al., 2016a). However, the $k_{\mathrm{a}} \mathrm{VFA}$ was not affected by the concentrate treatments (Dieho et al., 2016b, 2017). The aim of our study was to test the hypothesis that changes in the expression of 22 selected genes in rumen papillae reflect the observed changes in papillae morphology and VFA absorption. In addition, we hypothesized that the expression of 5 selected genes and proteins involved in the absorption and metabolism of VFA in rumen epithelial tissue increased with greater daily VFA production and VFA absorption rates.

\section{MATERIALS AND METHODS}

All experimental procedures were approved by the Animal Care and Ethics Committee of Wageningen University \& Research and conducted under the Dutch Law on the Animal Experiment.

\section{Experimental Design, Management, and Sample Collection}

Samples originating from 2 experiments, the lactation experiment and the dry period experiment, were used, which have been reported in detail (Dieho et al., 2016a, 2017). Brief summaries of these experiments are presented below.

Lactation Experiment. The experiment conducted by Dieho et al. (2016a) with experimental treatments during the early lactation period after calving will be referred to as the lactation experiment. Twelve dry, rumen-cannulated Holstein-Friesian dairy cows entered the experiment $8 \mathrm{wk}$ before the expected date of calving. Cows had free access to a mixed basal ration, consisting of grass silage, corn silage, soybean meal, and (dry period only) chopped wheat straw. The dry period ration contained $603 \mathrm{~g}$ of $\mathrm{DM} / \mathrm{kg}$, providing 5.3 MJ of $\mathrm{NE}_{\mathrm{L}}$ (calculated according to Van Es, 1978) and $455 \mathrm{~g}$ of FOM (calculated according to Tamminga et al., 1994) per kilogram of DM. The basal lactation ration contained $466 \mathrm{~g}$ of $\mathrm{DM} / \mathrm{kg}$, providing $6.7 \mathrm{MJ}$ of $\mathrm{NE}_{\mathrm{L}}$ and $561 \mathrm{~g}$ of $\mathrm{FOM} / \mathrm{kg}$ of DM. After calving, all cows were fed $0.9 \mathrm{~kg}$ of DM/d concentrate up to $3 \mathrm{~d} \mathrm{pp}$. Treatment consisted of either a rapid (RAP; $1.0 \mathrm{~kg}$ of $\mathrm{DM} / \mathrm{d} ; \mathrm{n}=6)$ or gradual (GRAD; $0.25 \mathrm{~kg}$ of DM/d; $\mathrm{n}$ $=6$ ) increase of concentrate allowance (up to $10.9 \mathrm{~kg}$ of $\mathrm{DM} / \mathrm{d}$ ) starting at $4 \mathrm{~d} \mathrm{pp}$. The concentrate contained $892 \mathrm{~g}$ of $\mathrm{DM} / \mathrm{kg}$, providing 7.4 MJ of $\mathrm{NE}_{\mathrm{L}}$ and $682 \mathrm{~g}$ of FOM $/ \mathrm{kg}$ of DM. The dry period and basal lactation rations were fed once a day for ad libitum intake and cows were milked twice daily. Daily individual intake of the mixed ration and concentrate was recorded. Rumen papillae were collected for epithelial mRNA and protein expression analysis during the pretreatment period at $10 \mathrm{~d}$ antepartum (ap) and $3 \mathrm{~d} \mathrm{pp}$, and during the treatment period at 9,16 , and $44 \mathrm{~d}$ pp.

Dry Period Experiment. The experiment conducted by Dieho et al. (2017) with experimental treatments during the dry period will be referred to as the dry period experiment. Nine weeks before the expected calving date, 10 dry, rumen-cannulated HolsteinFriesian dairy cows entered the experiment. Cows were randomly assigned to a control $(\mathbf{C O N})$ or treatment 
group (SUP). From the start of the experiment up to calving, all cows had free access to a dry period ration consisting of grass silage, corn silage, soybean meal, and chopped wheat straw. Treatment started 28 $\mathrm{d}$ ap and consisted of supplemental concentrate (3.0 $\mathrm{kg}$ of $\mathrm{DM} / \mathrm{d}$ ) until the day of calving (SUP) or no supplemental concentrate (CON). After calving, both CON and SUP had free access to a basal lactation ration, consisting of grass silage, corn silage, and soybean meal. All cows were fed $0.9 \mathrm{~kg}$ of $\mathrm{DM} / \mathrm{d}$ of concentrate up to $3 \mathrm{~d} \mathrm{pp}$, which thereafter increased with $1.0 \mathrm{~kg}$ of $\mathrm{DM} / \mathrm{d}$ to a maximum of $8.9 \mathrm{~kg}$ of $\mathrm{DM} / \mathrm{d}$ from $11 \mathrm{~d} \mathrm{pp}$ onwards. The dry period ration contained $503 \mathrm{~g}$ of DM/ $\mathrm{kg}$, providing $5.3 \mathrm{MJ}$ of $\mathrm{NE}_{\mathrm{L}}$ and $476 \mathrm{~g}$ of $\mathrm{FOM} / \mathrm{kg}$ of DM. The basal lactation ration contained $409 \mathrm{~g}$ of DM/ $\mathrm{kg}$, providing 6.6 MJ of $\mathrm{NE}_{\mathrm{L}}$ and $547 \mathrm{~g}$ of $\mathrm{FOM} / \mathrm{kg}$ of $\mathrm{DM}$. The concentrate contained $890 \mathrm{~g}$ of $\mathrm{DM} / \mathrm{kg}$ (fed during both the dry period and lactation), providing 7.5 MJ of $\mathrm{NE}_{\mathrm{L}}$ and $685 \mathrm{~g}$ of $\mathrm{FOM} / \mathrm{kg}$ of DM. The dry period and basal lactation rations were fed once a day for ad libitum intake and lactating cows were milked twice daily. Daily individual intake of the mixed ration and concentrate were recorded. Rumen papillae were collected for epithelial mRNA and protein expression analysis 28,18 , and $8 \mathrm{~d}$ ap and $3,17,31$, and $45 \mathrm{~d} \mathrm{pp}$.

Rumen Papillae Collection. In both experiments, papillae were collected according to the procedure described by Dieho et al. (2016a). Briefly, on sampling days, papillae were collected from each cow from a completely evacuated and washed rumen. Papillae were collected from the ventral rumen sac (VRS), ventral blind rumen sac (VBS), and dorsal blind rumen sac (DBS). After gently rinsing with $0.9 \% \mathrm{NaCl}$ (Kirat et al., 2006), papillae (150-300 mg/sample) were placed in sterile cryogenic vials (Cryo.S, Greiner Bio-One GmbH, Kremsmünster, Austria), snap frozen in liquid nitrogen, and stored at $-80^{\circ} \mathrm{C}$ until processing.

\section{RNA Extraction and Real-Time Quantitative PCR}

Frozen rumen papillae were ground in liquid nitrogen with a pestle and mortar. The RNA was extracted using Trizol Reagent (ThermoFisher Scientific, Bleiswijk, the Netherlands) and subsequently subjected to an on-column DNase digestion to eliminate possible DNA contamination (NucleoSpin RNA II kit; MachereyNagel GmbH \& Co. KG, Düren, Germany). Total RNA concentrations and purity were determined by optical density measurement using a NanoDrop ND1000 (ThermoFisher Scientific). Quality of RNA was determined with a 2100 Bioanalyzer and RNA 6000 Nano LabChip kit (Agilent Technologies, Palo Alto, CA). Mean $( \pm$ SEM) RNA Integrity Number was 8.9 \pm 0.6 and ranged from 7.3 to 9.4. An aliquot of $250 \mathrm{ng}$ of total RNA was reverse transcribed with Superscript III (ThermoFisher Scientific) in the presence of random hexamers (Roche, Almere, the Netherlands) and deoxyribose nucleoside triphosphates (dNTP; Roche) at $25^{\circ} \mathrm{C}$ for $5 \mathrm{~min}, 50^{\circ} \mathrm{C}$ for $1 \mathrm{~h}$, and, to inactivate the enzyme, at $70^{\circ} \mathrm{C}$ for $15 \mathrm{~min}$. Real-time quantitative PCR was carried out in a ABI 7500 Real-Time PCR System (Applied Biosystems, Foster City, CA), and SensiMix SYBR Low-ROX mix (Bioline UK Ltd., London, UK) was employed on the basis of the manufacturers conditions (http://www.bioline.com/downloads/dl/file/ id/2676/sensimix_sybr_low-rox_kit_v8-manual.pdf).

The primers used for the PCR of 22 genes of interest, associated with apoptosis, VFA absorption, VFA metabolism, and 4 normalization genes (Table 1), were designed with Primer Express Software (ThermoFisher Scientific), and recommended primer sets spanning at least 1 intron were selected. Amplification conditions were $95^{\circ} \mathrm{C}$ for $10 \mathrm{~min}$, followed by 40 cycles of $95^{\circ} \mathrm{C}$ for $10 \mathrm{~s}, 60^{\circ} \mathrm{C}$ for $5 \mathrm{~s}$, and $72^{\circ} \mathrm{C}$ for $5 \mathrm{~s}$. A final melting protocol with ramping from 65 to $95^{\circ} \mathrm{C}$ with $0.5^{\circ} \mathrm{C}$ increments of $5 \mathrm{~s}$ each was performed, confirming the presence of a single amplicon. Agarose gel electrophoresis revealed single bands of expected mobility. Quantitative mRNA measurement was performed by establishing a linear calibration curve using 10-fold serial dilutions of cDNA template for corresponding genes. Amplification efficiency ranged between 90 and $100 \%$ (Table 1). As internal standards, expression of normalization genes importin 8 (IPO8), eukaryotic translation elongation factor 2 (eEF2), calmodulin 2 (CALM2), and keratin 6 (KRT6) were analyzed. NormFinder (Andersen et al., 2004) identified KRT6 as the most stable reference gene in both experiments. For this reason, absolute expression levels of genes of interest were normalized using their corresponding values of KRT6, which is thought to be a marker of keratinizing stratified squamous epithelia (Moll et al., 2008).

\section{Western Blotting}

Protein expression of propionyl-CoA carboxylase- $\alpha$ subunit (PCCA), monocarboxylate transporter 1 (MCT1), downregulated in adenoma (DRA = SLC26A3, anion exchanger member 3), $\mathrm{Na}^{+} / \mathrm{H}^{+}$antiporter member 2 (NHE2), and $\mathrm{Na}^{+} / \mathrm{K}^{+}$transporting ATPase subunit $\alpha 1$ (ATP1A1) was assessed in the VBS of cows in the lactation experiment by Western blot analysis. The VBS site was chosen because it was the most ventrally located sampling site, associated with the highest blood flow (Von Engelhardt and Hales, 1977). Sampling 3, 16, and $44 \mathrm{~d}$ pp were chosen as these captured the start, peak, and end of the differences in concentrate treatment between RAP and GRAD respectively (Dieho et 


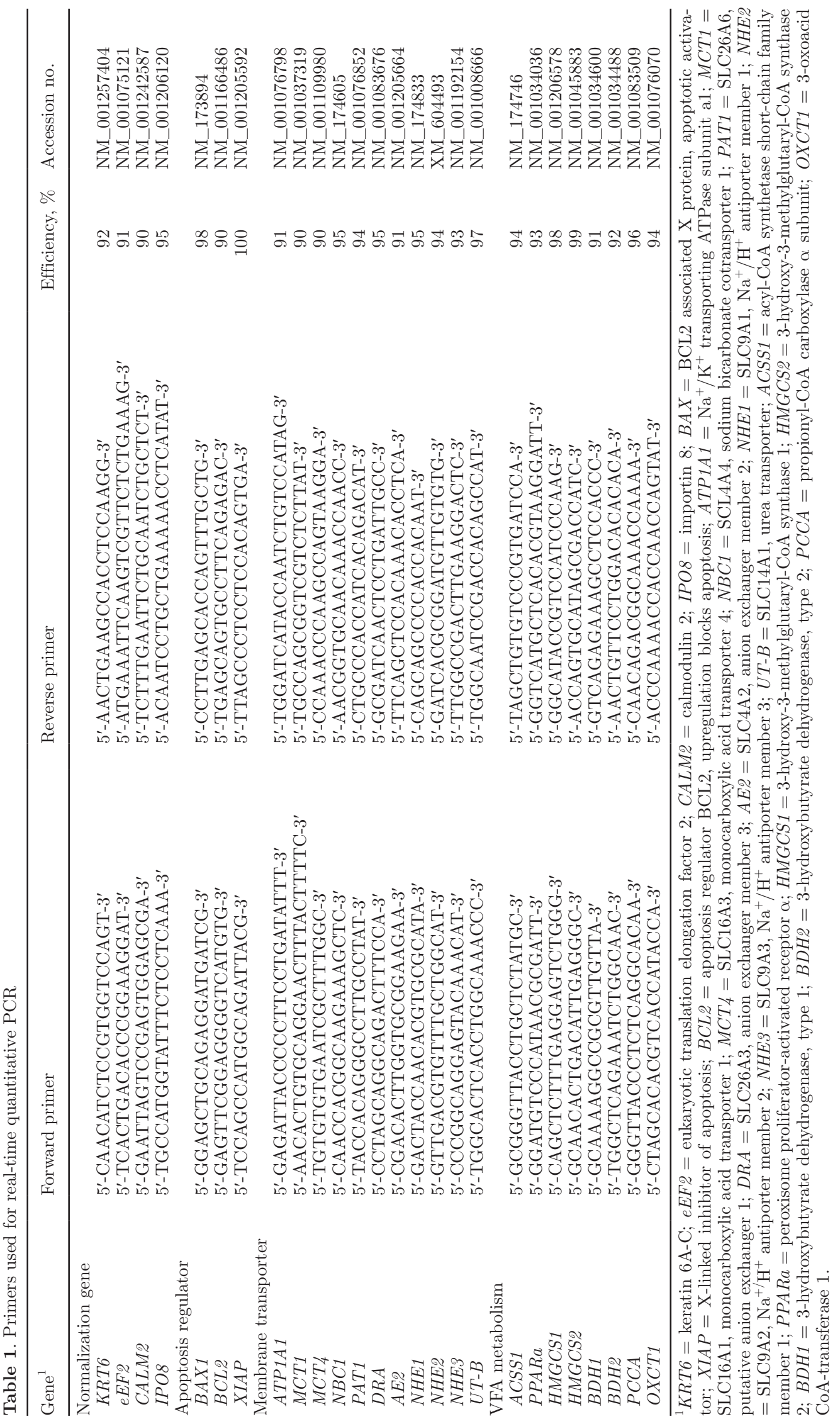


al., 2016a). Ground rumen biopsies were homogenized in a lysis buffer [50 $\mathrm{m} M$ Tris- $\mathrm{HCl} \mathrm{pH}$ 8.0, $150 \mathrm{mM}$ $\mathrm{NaCl}, 1,1 \%$ (vol/vol) NP-40, $1 \mathrm{~m} M$ phenylmethylsulfonyl fluoride] by rotating end-over-end at $4^{\circ} \mathrm{C}$ for $30 \mathrm{~min}$, followed by centrifugation at $14,000 \times g$ at $4^{\circ} \mathrm{C}$ for 10 min to remove insoluble material. Subsequently, protein concentrations were measured using a Coomassie Plus Bradford assay kit (ThermoFisher Scientific) with bovine serum albumin as a standard. Protein $(40 \mu \mathrm{g})$ was dissolved in a reducing buffer $(150 \mathrm{~m} M$ Tris- $\mathrm{HCl} \mathrm{pH}$ 8.5, $2 \%$ lithium dodecyl sulfate, $10 \%$ glycerol, $0.5 \mathrm{mM}$ EDTA, $0.2 \mathrm{~m} M$ SERVA Blue G, $0.15 \mathrm{~m} M$ Phenol Red), size fractionated by electrophoresis on precast NuPage Novex $4-12 \%$ Bis-Tris gels (ThermoFisher Scientific), and electroblotted to Immobilon-FL PVDF membranes (0.45 $\mu \mathrm{m}$; Li-Cor Biosciences, Bad Homburg, Germany) at a constant $80 \mathrm{~V}$ for $90 \mathrm{~min}$. Membranes were blocked with Blocking Solution (Odyssey; Li-Cor Biosciences, Bad Homburg, Germany) diluted 1:1 in PBS for 1 $\mathrm{h}$ at room temperature, and probed overnight $\left(4^{\circ} \mathrm{C}\right)$ with either polyclonal rabbit anti-PCCA or anti-DRA antibody (LifeSpan Biosciences, Seattle, WA), polyclonal chicken anti-MCT1 (Merck Millipore, Amsterdam, the Netherlands), polyclonal goat anti-NHE-2 (Santa Cruz Biotechnology, Heidelberg, Germany), or monoclonal mouse anti-ATP1A1 antibody (Abcam, Cambridge, UK), all diluted 1:2,000 in PBS containing $0.1 \%$ Tween-20. Subsequently, blots were incubated with IRDye-800-conjugated donkey polyclonal secondary antibody (Li-Cor Biosciences, diluted 1:15,000 in PBS) for $30 \mathrm{~min}$ at room temperature. Finally, positive bands were detected using an Odyssey infrared imaging system (Li-Cor Biosciences). As a loading control, blots were reprobed with monoclonal mouse antiACTB (Abcam, 1:5,000) and visualized with IRDye680-conjugated donkey anti-mouse antibody (Li-Cor Biosciences, 1:20,000). The sizes of the detected bands were consistent to those described for MCT1 (Koho et al., 2005), DRA (Hayashi and Yamashita, 2012), NHE2 (Lam et al., 2009), ATP1A1 (Hickey and Buhr, 2012), and PCCA (Ballhausen et al., 2009). Band density was measured with the software program ImageJ (http:// rsb.info.nih.gov/ij/index.html) and normalized to ACTB.

\section{Calculations and Statistical Analysis}

The gene expression data were $\log _{10}$-transformed before analysis to achieve normal distribution. Gene and protein expression data were analyzed using the MIXED procedure (Littell et al., 2006) in SAS 9.3 (SAS Institute Inc., Cary, NC) with the model

$$
Y_{i j k l}=\mu+T_{i}+S_{k}+D_{l}+(T \times D)_{i l}+D(C)_{j l}+e_{i j k l},
$$

where variable $Y_{i j k l}$ was dependent on $\mu$ as the average experimental value and fixed main effects of concentrate treatment $T_{i}(i=\mathrm{RAP}, \mathrm{GRAD}$ for the lactation experiment or CON, SUP for the dry period experiment, respectively), sampling day $D_{l}$ (gene expression data, $l=-10, \ldots, 44$ for the lactation experiment, and $-28, \ldots, 45$ for the dry period experiment; protein expression data, $l=3,16$, and $44 \mathrm{~d}$ pp for the lactation experiment), site $S_{k}(k=\mathrm{VRS}$, VBS, DBS; not applicable for protein expression data) and interaction $(T \times D)_{i l}$. Random effects of sampling day within cows, $D(C)_{j l}$, were included, avoiding pseudoreplication due to multiple biopsy sites $S_{k}$ (Dieho et al., 2016a). Errors $e_{i j k l}$ were assumed to be autocorrelated for repeated observations on the same cow and site, using a spatial power covariance structure over sampling days (Littell et al., 1998). For the gene expression data from the lactation experiment, CONTRAST statements were formulated adapted from Dieho et al. (2016a) to test for $T_{i}$ and ( $T$ $\times D)_{i l}$ as the study design could not be treated as fully factorial. All other data, for which sampling site within the rumen was not applicable, were analyzed with a reduced model by removing $S_{k}$ and $D(C)_{j l}$, with repeated measurements on the same cow. To test specific hypotheses, CONTRAST or ESTIMATE statements were formulated to separate means. All results are reported as least squares means with their standard error unless indicated otherwise. Significance of effect was declared at $P<0.05$ and trends at $0.05 \leq P<0.10$.

\section{RESULTS}

During the lactation experiment, 1 cow (RAP) calved early, missing sampling at $10 \mathrm{~d}$ ap; otherwise, all samples were collected (Dieho et al., 2016a). During the dry period experiment, 1 cow (SUP) calved early (stillbirth), and subsequently developed endometritis and a displaced abomasum requiring surgery. To aid recovery, the animal was removed from the experiment and all data relating to this cow were excluded from analysis (Dieho et al., 2017).

\section{Feed Intake, Rumen Fluid Composition, and Adaptation of the Rumen}

For the lactation experiment, feed intake, rumen fluid composition, and morphological adaptation of the rumen were reported in detail by Dieho et al. (2016a), and changes in $k_{\mathrm{a}} \mathrm{VFA}$ and daily VFA production were reported by Dieho et al. (2016b). Briefly, after calving, both DMI and FOM intake increased for RAP and GRAD, and the rapid increase in concentrate allowance resulted in a greater FOM intake at $16 \mathrm{~d}$ pp in RAP than GRAD. Papillae surface area increased after 
calving and was greater during the lactation than the dry period, and surface area increased faster for RAP compared with GRAD and was greater at 16 and $44 \mathrm{~d}$ pp for RAP than GRAD (Figure $1 \mathrm{~A}$ ). The $k_{\mathrm{a}} \mathrm{VFA}$ increased after calving and was greater during the lactation than the dry period (Figure 1A); however, despite the greater papillae surface area in RAP than GRAD, no differences in $k_{\mathrm{a}} \mathrm{VFA}$ between RAP and GRAD were observed at 16 and $44 \mathrm{~d}$ pp. Total daily VFA production increased after calving and was numerically greater in RAP than GRAD at $16 \mathrm{~d} p \mathrm{pp}$, whereas propionate production was greater RAP than GRAD on that day. Total VFA concentration in the rumen fluid increased from $79.5 \mathrm{~m} M$ during the dry period to $96.4 \mathrm{~m} M$ at $3 \mathrm{~d}$ $\mathrm{pp}$, and further to $120 \mathrm{mM}$ at $44 \mathrm{~d} \mathrm{pp}$. Rumen fluid $\mathrm{pH}$ decreased from 6.71 during the dry period to 6.27 at $3 \mathrm{~d}$ pp, further decreasing to 6.07 at $44 \mathrm{~d}$ pp. Neither total VFA nor $\mathrm{pH}$ was affected by the concentrate treatment.

For the dry period experiment, feed intake, morphological adaptation of the rumen, and changes in $k_{\mathrm{a}} \mathrm{VFA}$ have been reported by Dieho et al. (2017). Feeding supplemental concentrate during the dry period was reflected by a consistent numerically greater FOM intake at 18 and $8 \mathrm{~d}$ ap for SUP compared with CON. After calving, DMI and FOM intake increased for both SUP and CON compared with the dry period. Papillae surface area increased for SUP but not for CON during the dry period (Figure 1B); however, the increase in surface area for SUP was temporary and was not present from $3 \mathrm{~d}$ pp onwards. No differences in $k_{\mathrm{a}} \mathrm{VFA}$ between SUP and CON were observed during the dry period or lactation. In line with the lactation experiment, papillae surface area and $k_{\mathrm{a}} \mathrm{VFA}$ increased after calving and were greater during lactation than the dry period. Rumen fluid VFA concentration was affected by the supplemental concentrate treatment during the dry period. At $18 \mathrm{~d}$ ap, total VFA concentration was 33 $\mathrm{m} M$ higher for SUP $(120 \mathrm{~m} M)$ than CON $(87 \mathrm{~m} M)$, but no difference was found and $8 \mathrm{~d}$ ap. After calving, rumen VFA concentration tended to increase to a peak of $115 \mathrm{~m} M$ at $31 \mathrm{~d}$ pp. At $18 \mathrm{~d}$ ap, rumen $\mathrm{pH}$ was lower for SUP (6.43) than CON (6.83). After calving rumen fluid $\mathrm{pH}$ was lower at 3 and $17 \mathrm{~d} \mathrm{pp}$ for CON (6.13 and 5.95, respectively) than SUP (6.72 and 6.43, respectively).

\section{Expression of Genes Associated with Apoptosis}

In both experiments, mRNA expression of the apoptotic inhibitors XIAP and BCL2 and expression of the apoptotic activator $B A X 1$ were not affected by sampling day or by an interaction between sampling day and treatment (Table 2 and 3). The expression of XIAP was not affected by the treatments $(P \geq 0.30)$. The expression of $B C L 2$ was not affected by concentrate treatment in the lactation experiment $(P=0.89)$, but tended $(P=0.08)$ to be lower in SUP compared with $\mathrm{CON}$ in the dry period experiment. The expression of $B A X 1$ tended to be greater $(P=0.08)$ for RAP than GRAD in the lactation period experiment, and was greater $(P=0.01)$ for SUP than CON in the dry period experiment. The BCL2/BAX ratio was not affected by an interaction between sampling day and treatment for the lactation experiment $(P=0.21)$. An interaction was observed for the dry period experiment $(P<0.01)$,
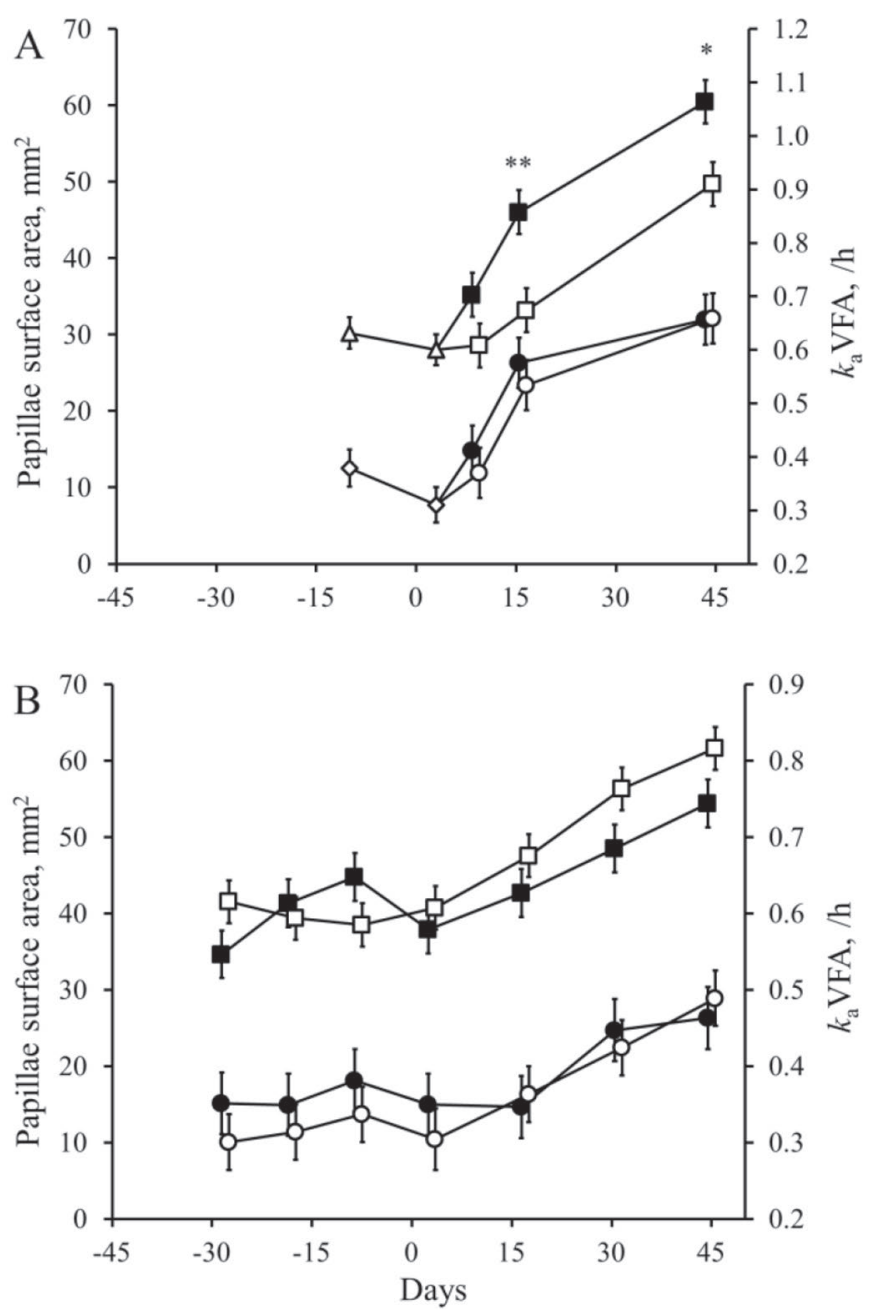

Figure 1. (A) Rumen papilla surface area $\left(\mathrm{mm}^{2} ; \Delta \square \square\right)$ and fractional rate of VFA absorption $\left(k_{\mathrm{a}} \mathrm{VFA}\right.$, per hour; $\left.\diamond \bullet\right)$ during the pretreatment period $(\diamond \Delta ; \mathrm{n}=12)$, and the treatment period for a rapid $(1.0 \mathrm{~kg}$ of $\mathrm{DM} / \mathrm{d} ; \boldsymbol{\square}, \mathrm{n}=6)$ and gradual $(0.25 \mathrm{~kg}$ of $\mathrm{DM} / \mathrm{d} ; \square$, $\mathrm{n}=6$ ) rate of increase of concentrate allowance postpartum. Adapted from Dieho et al. (2016a,b). (B) Rumen papilla surface area $\left(\mathrm{mm}^{2}\right.$; $\square$ ) and fractional rate of VFA absorption $(/ \mathrm{h} ; \bullet \bigcirc)$ for a control dry period ration (no concentrate, $\square \bigcirc ; \mathrm{n}=5$ ) and dry period ration with supplemental concentrate (3.0 kg of DM/d of concentrate, $\mathbf{\square} ; \mathrm{n}=4)$, and the subsequent lactation. Adapted from Dieho et al. (2017). Day $=$ day relative to calving. Values represent $\mathrm{LSM} \pm \mathrm{SE} ; * P<0.05,{ }^{*} P$ $<0.01$, significance of differences in LSM of CON and SUP for the same sampling day and variable. Values are slightly offset for clarity. 
Table 2. Least squares means of $\log _{10}$-transformed expression of genes in the rumen papillae associated with apoptosis during the lactation experiment with a rapid rate of increase $(\mathrm{RAP} ; 1.0 \mathrm{~kg}$ of $\mathrm{DM} / \mathrm{d} ; \mathrm{n}=6)$ of concentrate allowance or gradual rate of increase (GRAD; $0.25 \mathrm{~kg}$ of $\mathrm{DM} / \mathrm{d} ; \mathrm{n}=6)$ of concentrate allowance postpartum ${ }^{1}$

\begin{tabular}{|c|c|c|c|c|c|c|c|c|c|c|c|}
\hline \multirow{2}{*}{ Gene } & \multirow{2}{*}{ Rate } & \multicolumn{5}{|c|}{ Sampling day relative to calving } & \multirow{2}{*}{$\mathrm{SE}^{2}$} & \multirow{2}{*}{\multicolumn{4}{|c|}{$\frac{\text { Fixed effect }}{3}$}} \\
\hline & & \multicolumn{2}{|c|}{ Pretreatment period } & \multicolumn{3}{|c|}{ Treatment period } & & & & & \\
\hline$B A X 1$ & $\begin{array}{l}\text { RAP } \\
\text { GRAD }\end{array}$ & $\begin{array}{l}-1.08 \\
-1.17\end{array}$ & $\begin{array}{l}-1.03 \\
-1.21\end{array}$ & $\begin{array}{l}-1.10 \\
-1.13\end{array}$ & $\begin{array}{l}-1.03 \\
-1.14\end{array}$ & $\begin{array}{l}-1.11 \\
-1.12\end{array}$ & 0.025 & 0.08 & 0.83 & $<0.01$ & 0.16 \\
\hline$B C L 2$ & $\begin{array}{l}\text { RAP } \\
\text { GRAD }\end{array}$ & $\begin{array}{l}-1.36 \\
-1.43\end{array}$ & $\begin{array}{l}-1.38 \\
-1.40\end{array}$ & $\begin{array}{l}-1.39 \\
-1.41\end{array}$ & $\begin{array}{l}-1.35 \\
-1.40\end{array}$ & $\begin{array}{l}-1.45 \\
-1.39\end{array}$ & 0.027 & 0.89 & 0.84 & $<0.01$ & 0.55 \\
\hline$X I A P$ & $\begin{array}{l}\text { RAP } \\
\text { GRAD }\end{array}$ & $\begin{array}{l}-0.79 \\
-0.91\end{array}$ & $\begin{array}{l}-0.84 \\
-0.91\end{array}$ & $\begin{array}{l}-0.88 \\
-0.88\end{array}$ & $\begin{array}{l}-0.85 \\
-0.91\end{array}$ & $\begin{array}{l}-0.85 \\
-0.88\end{array}$ & 0.023 & 0.30 & 0.92 & $<0.01$ & 0.60 \\
\hline
\end{tabular}

${ }^{1}$ Expression was normalized against keratin-6.

${ }^{2}$ Standard error for LSM by sampling day; $\mathrm{n}=12$.

${ }^{3} \mathrm{~T}=$ treatment, $P$-value for treatment period $(\mathrm{d} 9$ to 44$) ; \mathrm{D}=$ sampling day, $P$-value for pretreatment and treatment period $(\mathrm{d}-10$ to 44$) ; \mathrm{S}=$ sampling site within the rumen; $\mathrm{T} \times \mathrm{D}=$ interaction between treatment and sampling day, $P$-value for treatment period (d 9 to 44 ).

${ }^{4}$ Group GRAD: $\mathrm{n}=5,1$ cow had no measurement at $\mathrm{d}-10$ due to early calving.

with a greater ratio for SUP than CON at 28 and 18 $\mathrm{d}$ ap and $3 \mathrm{~d}$ pp $(P \leq 0.05)$, and a tendency for a greater ratio for SUP at $8 \mathrm{~d}$ ap and $45 \mathrm{~d}$ pp $(P \leq$ $0.09)$; however, the BCL2/BAX ratio was not affected by sampling day $(P \geq 0.30)$.

\section{Expression of Genes Associated with VFA Absorption, Intracellular $\mathrm{pH}$, and Urea Transport}

During the lactation experiment, except for a postpartum increase for $\mathrm{Na}^{+} / \mathrm{HCO}_{3}{ }^{-}$cotransporter $N B C 1$ $(P=0.04)$, no effects of sampling day $(P \geq 0.10)$ were observed on the mRNA expression of the membrane transporters ATP1A1, MCT1, MCT4, DRA, PAT1, AE2, NHE1, NHE2, NHE3, and UT-B (Table 4). The concentrate treatment during early lactation did not affect the expression of most of the absorption- related genes. The expression of monocarboxylate transporter MCT4 tended $(P<0.08)$ to be greater with RAP than with GRAD, and expression of $\mathrm{VFA}^{-} / \mathrm{HCO}_{3}{ }^{-}$exchanger PAT1 tended to be greater $(P=0.05)$ for RAP than GRAD. No interaction between treatment and sampling day was observed for the absorption-related genes $(P \geq 0.20)$.

During the dry period experiment, sampling day affected the mRNA levels of the $\mathrm{Na}^{+} / \mathrm{H}^{+}$exchangers

Table 3. Least squares means of $\log _{10}$-transformed expression of genes in the rumen papillae associated with tissue apoptosis during the dry period experiment for the control (no concentrate during the dry period; CON, $\mathrm{n}=5$ ) and supplemental concentrate treatment $(3.0 \mathrm{~kg}$ of $\mathrm{DM} / \mathrm{d}$ of concentrate during the dry period; SUP, $\left.\mathrm{n}=4^{1}\right)^{2}$

Sampling day relative to calving

\begin{tabular}{|c|c|c|c|c|c|c|c|c|c|c|c|c|c|}
\hline \multirow[b]{3}{*}{ Gene } & \multirow[b]{3}{*}{ Group } & \multicolumn{7}{|c|}{ Sampling day relative to calving } & \multirow[b]{3}{*}{$\mathrm{SE}^{3}$} & \multicolumn{4}{|c|}{ Fixed effect ${ }^{4}$} \\
\hline & & \multirow[b]{2}{*}{-28} & \multirow[b]{2}{*}{-18} & \multirow[b]{2}{*}{-8} & \multirow[b]{2}{*}{3} & \multirow[b]{2}{*}{17} & \multirow[b]{2}{*}{31} & \multirow[b]{2}{*}{45} & & \multicolumn{4}{|c|}{$P$-value } \\
\hline & & & & & & & & & & $\mathrm{T}$ & $\mathrm{D}$ & $\mathrm{S}$ & $\mathrm{T} \times \mathrm{D}$ \\
\hline \multirow[t]{2}{*}{$B A X 1$} & $\mathrm{CON}$ & -0.91 & -0.96 & -0.91 & -0.91 & -0.93 & -0.97 & -0.94 & 0.024 & 0.01 & 0.27 & $<0.01$ & 0.22 \\
\hline & SUP & -0.88 & -0.80 & -0.85 & -0.86 & -0.88 & -0.95 & -0.88 & & & & & \\
\hline \multirow[t]{2}{*}{ BCL2 } & $\mathrm{CON}$ & -1.71 & -1.73 & -1.72 & -1.69 & -1.73 & -1.77 & -1.77 & 0.038 & 0.08 & 0.65 & $<0.01$ & 0.98 \\
\hline & SUP & $\begin{array}{c}-1.79 \\
*\end{array}$ & $\begin{array}{c}-1.78 \\
* *\end{array}$ & $\begin{array}{c}-1.73 \\
\dagger\end{array}$ & $\begin{array}{c}-1.77 \\
*\end{array}$ & -1.73 & -1.85 & $\begin{array}{c}-1.79 \\
\dagger\end{array}$ & & & & & \\
\hline \multirow[t]{2}{*}{$B C L 2 / B A X 1$} & $\mathrm{CON}$ & 1.91 & 1.81 & 1.89 & 1.87 & 1.88 & 1.84 & 1.89 & 0.066 & $<0.01$ & 0.30 & $<0.01$ & $<0.01$ \\
\hline & SUP & 2.09 & 2.31 & 2.06 & 2.08 & 1.98 & 1.97 & 2.05 & & & & & \\
\hline \multirow[t]{2}{*}{$X I A P$} & $\mathrm{CON}$ & -0.85 & -0.88 & -0.88 & -0.84 & -0.93 & -0.94 & -0.94 & 0.033 & 0.64 & 0.29 & $<0.01$ & 0.77 \\
\hline & SUP & -0.91 & -0.87 & -0.87 & -0.82 & -0.85 & -0.97 & -0.89 & & & & & \\
\hline
\end{tabular}

${ }^{1}$ Group SUP: $\mathrm{n}=4,1$ cow was removed from the experiment.

${ }^{2}$ Expression was normalized against keratin-6.

${ }^{3}$ Standard error for LSM by sampling day; $\mathrm{n}=9$.

${ }^{4} \mathrm{~T}=$ treatment $; \mathrm{D}=$ sampling day; $\mathrm{S}=$ sampling site within the rumen; $\mathrm{T} \times \mathrm{D}=$ interaction between treatment and sampling day.

$\dagger P<0.10,{ }^{*} P<0.05,{ }^{*} P<0.01$, significance of difference in LSM of CON or SUP for the same sampling day and gene. 
NHE2 and NHE3 $(P \leq 0.03)$, but not NHE1 $(P=$ 0.98 ; Table 5). The expression of NHE2 decreased toward calving, peaked at $3 \mathrm{~d} \mathrm{pp}$, and decreased again afterward, whereas that of NHE3 was lower during the lactation period compared with the dry period. The mRNA expression of $N B C 1$ was affected by sampling day $(P<0.01)$ and decreased after calving compared with the dry period. In addition, a tendency $(P=0.06)$ for an interaction between sampling day and treatment was observed, with greater expression of $N B C 1$ for SUP at $17 \mathrm{~d}$ pp compared with CON $(P<0.01)$. The mRNA expression of PAT1 and AE2 was not affected $(P \geq$ 0.36 ) by treatment, sampling day, or their interaction, whereas mRNA expression of $\mathrm{VFA}^{-} / \mathrm{HCO}_{3}{ }^{-}$exchanger $D R A$ was affected by sampling day $(P=0.04)$ and decreased after calving compared with the dry period. The mRNA expression of MCT1, but not MCT4, and that of urea transporter $U T-B$ were affected by sampling day $(P \leq 0.04)$, both showing a peak at $3 \mathrm{~d}$ pp. For ATP1A1, encoding the a1-subunit of $\mathrm{Na}^{+} / \mathrm{K}^{+}$-ATPase, an interaction between treatment and sampling day was observed $(P=0.02)$, with greater $(P<0.01)$ mRNA expression at 18 and $8 \mathrm{~d}$ ap in SUP compared with
CON and a tendency for lower expression at $31 \mathrm{~d} p p$ $(P=0.09)$. A treatment effect was observed for MCT4, $N B C 1, D R A$, and NHE3 $(P \leq 0.03)$ and a tendency for NHE2 $(P=0.10)$, generally showing a greater mRNA expression for SUP than CON.

\section{Expression of Genes Associated with VFA Metabolism}

During the lactation experiment (Table 6), the mRNA expression of HMG-CoA synthase 1, HMGCS1, and succinyl-CoA:3-oxoacid CoA transferase, OXCT1, tended to be affected by sampling day $(P=0.07)$. However, we found no clear pattern of change in expression over sampling days. Expression of HMGCS-2 and 3-hydroxybutyrate dehydrogenase type $1, B D H 1$, tended ( $P$ $=0.10)$ to increase after calving. A treatment effect was observed only for the mRNA expression of peroxisome proliferator activated receptor $\alpha$ PPARa and $B D H 2(P \leq 0.04)$, with greater expression in cows from RAP compared with GRAD, with the expression level of PPARa and BDH2 already being greater during the pretreatment period in RAP compared with GRAD.

Table 4. Least squares means of $\log _{10}$-transformed expression of genes in the rumen papillae associated with VFA absorption and maintenance of intracellular $\mathrm{pH}$ during the lactation experiment with a rapid rate of increase $(\mathrm{RAP} ; 1.0 \mathrm{~kg}$ of $\mathrm{DM} / \mathrm{d} ; \mathrm{n}=6)$ of concentrate allowance or gradual rate of increase (GRAD; $0.25 \mathrm{~kg}$ of $\mathrm{DM} / \mathrm{d} ; \mathrm{n}=6$ ) of concentrate allowance postpartum

\begin{tabular}{|c|c|c|c|c|c|c|c|c|c|c|c|}
\hline \multirow[b]{3}{*}{ Gene } & \multirow[b]{3}{*}{ Rate } & \multicolumn{5}{|c|}{ Sampling day relative to calving } & \multirow[b]{3}{*}{$\mathrm{SE}^{2}$} & \multicolumn{4}{|c|}{ Fixed effect ${ }^{3}$} \\
\hline & & \multicolumn{2}{|c|}{ Pretreatment period } & \multicolumn{3}{|c|}{ Treatment period } & & \multicolumn{4}{|c|}{$P$-value } \\
\hline & & $-10^{4}$ & 3 & 9 & 16 & 44 & & $\mathrm{~T}$ & $\mathrm{D}$ & $\mathrm{S}$ & $\mathrm{T} \times \mathrm{D}$ \\
\hline \multirow[t]{2}{*}{$A T P 1 A 1$} & RAP & 0.69 & 0.64 & 0.62 & 0.64 & 0.61 & 0.028 & 0.19 & 0.74 & $<0.01$ & 0.36 \\
\hline & GRAD & 0.60 & 0.59 & 0.59 & 0.55 & 0.60 & & & & & \\
\hline \multirow[t]{2}{*}{$M C T 1$} & RAP & 1.52 & 1.57 & 1.57 & 1.62 & 1.53 & 0.032 & 0.33 & 0.48 & $<0.01$ & 0.58 \\
\hline & GRAD & 1.46 & 1.55 & 1.54 & 1.53 & 1.53 & & & & & \\
\hline \multirow[t]{2}{*}{$M C T 4$} & RAP & 0.26 & 0.26 & 0.18 & 0.28 & 0.19 & 0.039 & 0.08 & 0.25 & $<0.01$ & 0.20 \\
\hline & GRAD & 0.19 & 0.02 & 0.09 & 0.15 & 0.19 & & & & & \\
\hline \multirow[t]{2}{*}{$N B C 1$} & RAP & -0.69 & -0.72 & -0.74 & -0.77 & -0.59 & 0.064 & 0.26 & 0.04 & $<0.01$ & 0.39 \\
\hline & GRAD & -0.77 & -0.94 & -0.87 & -0.74 & -0.67 & & & & & \\
\hline \multirow[t]{2}{*}{ PAT1 } & RAP & 0.02 & 0.10 & 0.08 & 0.14 & 0.03 & 0.032 & 0.05 & 0.39 & 0.01 & 0.41 \\
\hline & GRAD & -0.04 & 0.06 & 0.04 & -0.02 & 0.01 & & & & & \\
\hline \multirow[t]{2}{*}{$D R A$} & RAP & 0.24 & 0.28 & 0.36 & 0.37 & 0.38 & 0.044 & 0.41 & 0.10 & $<0.01$ & 0.72 \\
\hline & GRAD & 0.18 & 0.37 & 0.30 & 0.32 & 0.39 & & & & & \\
\hline \multirow[t]{2}{*}{$A E 2$} & RAP & 0.24 & 0.21 & 0.15 & 0.17 & 0.10 & 0.029 & 0.48 & 0.28 & $<0.01$ & 0.82 \\
\hline & GRAD & 0.14 & 0.12 & 0.12 & 0.12 & 0.14 & & & & & \\
\hline \multirow[t]{2}{*}{ NHE1 } & RAP & 0.30 & 0.28 & 0.23 & 0.25 & 0.22 & 0.031 & 0.95 & 0.88 & $<0.01$ & 0.90 \\
\hline & GRAD & 0.24 & 0.20 & 0.25 & 0.21 & 0.23 & & & & & \\
\hline \multirow[t]{2}{*}{ NHE2 } & RAP & 0.77 & 0.82 & 0.84 & 0.85 & 0.86 & 0.028 & 0.35 & 0.14 & $<0.01$ & 0.49 \\
\hline & GRAD & 0.74 & 0.84 & 0.86 & 0.78 & 0.82 & & & & & \\
\hline \multirow[t]{2}{*}{ NHE3 } & RAP & 0.88 & 0.90 & 0.87 & 0.86 & 0.86 & 0.037 & 0.91 & 0.86 & 0.78 & 0.86 \\
\hline & GRAD & 0.80 & 0.85 & 0.86 & 0.81 & 0.91 & & & & & \\
\hline \multirow[t]{2}{*}{$U T-B$} & RAP & 0.63 & 0.71 & 0.72 & 0.77 & 0.72 & 0.034 & 0.40 & 0.30 & $<0.01$ & 0.78 \\
\hline & GRAD & 0.65 & 0.76 & 0.70 & 0.70 & 0.70 & & & & & \\
\hline
\end{tabular}

${ }^{1}$ Expression was normalized against keratin-6.

${ }^{2}$ Standard error for LSM by sampling day; $\mathrm{n}=12$.

${ }^{3} \mathrm{~T}=$ treatment, $P$-value for treatment period (d 9 to 44$) ; \mathrm{D}=$ sampling day, $P$-value for pretreatment and treatment period $(\mathrm{d}-10$ to 44$) ; \mathrm{S}=$ sampling site within the rumen; $\mathrm{T} \times \mathrm{D}=$ interaction between treatment and sampling day, $P$-value for treatment period $(\mathrm{d} 9$ to 44$)$.

${ }^{4}$ Group GRAD: $\mathrm{n}=5,1$ cow had no measurement at $\mathrm{d}-10$ due to early calving. 
Table 5. Least squares means of $\log _{10}$-transformed expression of genes in the rumen papillae associated with VFA absorption and maintenance of intracellular $\mathrm{pH}$ during the dry period experiment with the control $(\mathrm{CON}$; no concentrate during the dry period; $\mathrm{n}=5)$ and supplemental concentrate treatment (SUP; $3.0 \mathrm{~kg}$ of DM/d concentrate during the dry period; $\left.\mathrm{n}=4^{1}\right)^{2}$

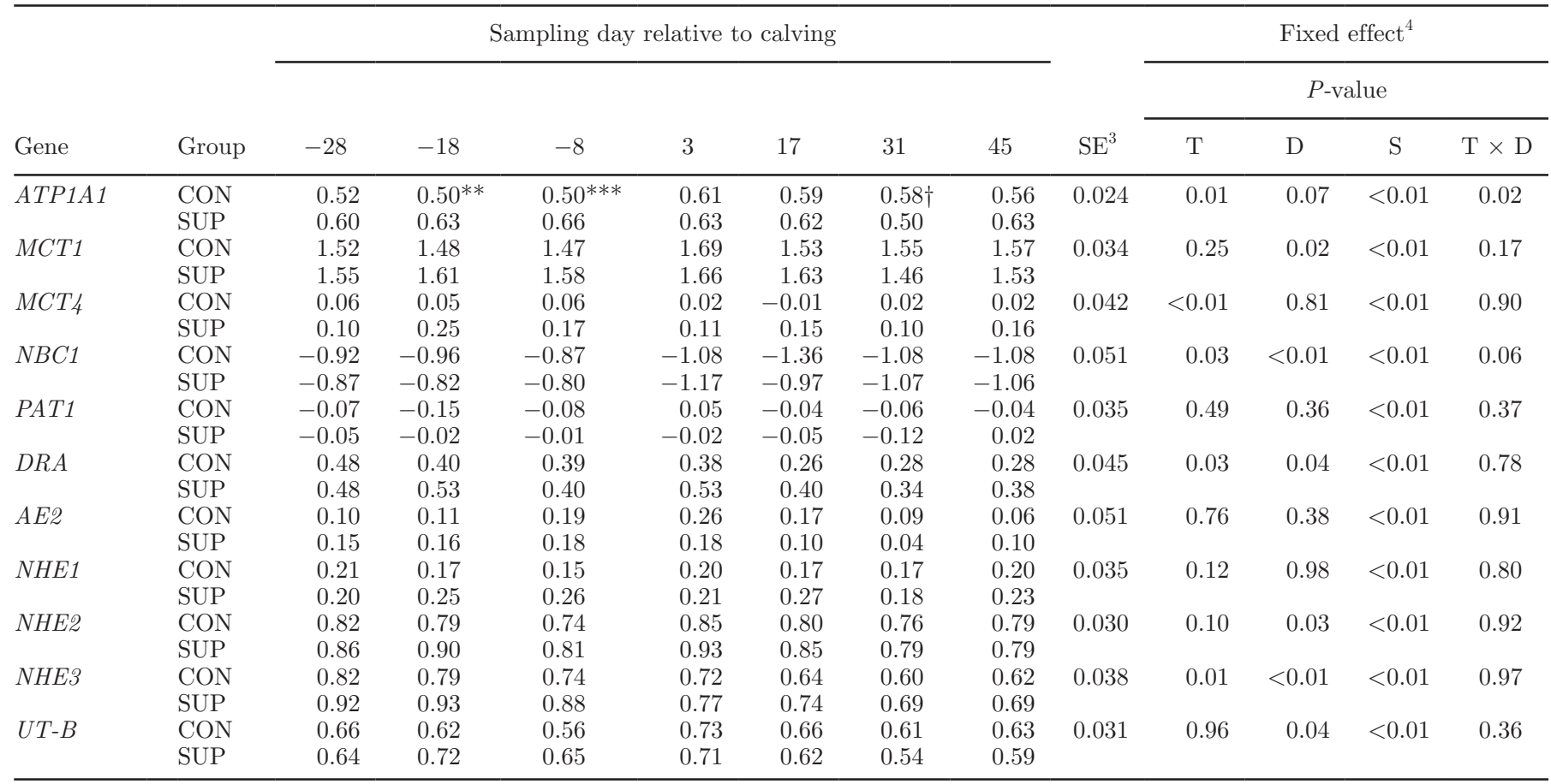

${ }^{1}$ Group SUP: $\mathrm{n}=4,1$ cow was removed from the experiment.

${ }^{2}$ Expression was normalized against keratin-6

${ }^{3}$ Standard error for LSM by sampling day; $\mathrm{n}=9$.

${ }^{4} \mathrm{~T}=$ treatment $\mathrm{D}=$ sampling day; $\mathrm{S}=$ sampling site within the rumen; $\mathrm{T} \times \mathrm{D}=$ interaction between treatment and sampling day.

$\dagger P<0.10,{ }^{* *} P<0.01,{ }^{* * *} P<0.001$, significance of difference in LSM of CON or SUP for the same sampling day and gene.

No interaction between treatment and sampling day was observed for any of the measured VFA metabolismrelated genes $(P \geq 0.11)$.

During the dry period experiment, sampling day affected $(P=0.01)$ only the mRNA expression of HMGCoA synthase 2 (HMGCS2), showing a peak at $3 \mathrm{~d}$ pp (Table 7). The mRNA abundance of acetyl-CoA synthetase 1 ACSS1, BDH1, BDH2, and OXCT1 was greater $(P \leq 0.03)$, and that of PPARa was lower $(P$ $<0.01)$ in SUP compared with CON. A tendency for a treatment and sampling day interaction was only observed for mRNA expression of HMGCS1 $(P=0.06)$, with expression tending to be greater in SUP compared with $\mathrm{CON}$ at $18 \mathrm{~d}$ ap $(P=0.05)$ and $8 \mathrm{~d}$ ap $(P=0.10)$, but lower in SUP compared with CON at $3 \mathrm{~d}$ pp $(P=$ $0.09)$.

\section{Expression of Genes at Different Sites in the Rumen}

In both experiments, site of collection of the papillae affected the mRNA expression of all genes examined $(P \leq 0.01)$, except for NHE3 $(P=0.78)$, during the lactation experiment (Table 2-8). The expression of apoptosis-related genes was generally highest in VBS for the lactation experiment, but not for the dry period experiment. In the dry period experiment, expression of VFA transporter genes was generally lowest in VBS; such a pattern did not occur in the lactation experiment. Similarly, expression of VFA metabolism genes was generally highest in VRS for the dry period experiment, but this was not the case for the lactation experiment.

\section{Expression of Proteins Associated with VFA Absorption and Metabolism}

An interaction was observed for treatment and sampling day for the ruminal expression of MCT1 protein $(P=0.02$; Figure 2). Expression of MCT1 increased by $32 \%$ in RAP from 3 to $16 \mathrm{~d}$ pp $(P=0.01)$, but at $44 \mathrm{~d}$ pp did not differ from $3 \mathrm{~d}$ and $16 \mathrm{~d}$ pp $(P=$ 0.12 ), whereas expression of MCT1 did not change in GRAD $(P \geq 0.16)$. Expression of DRA was affected by sampling day $(P<0.01)$ and peaked at $16 \mathrm{~d}$ pp, with 
Table 6. Least squares means of $\log _{10}$-transformed expression of genes in the rumen papillae associated with VFA metabolism during the lactation experiment with a rapid rate of increase (RAP; $1.0 \mathrm{~kg}$ of DM/d; $\mathrm{n}=6$ ) of concentrate allowance or gradual rate of increase (GRAD; $0.25 \mathrm{~kg}$ of $\mathrm{DM} / \mathrm{d} ; \mathrm{n}=6$ ) of concentrate allowance postpartum ${ }^{1}$

\begin{tabular}{|c|c|c|c|c|c|c|c|c|c|c|c|}
\hline \multirow[b]{2}{*}{ Gene } & \multirow[b]{2}{*}{ Rate } & \multicolumn{5}{|c|}{ Sampling day relative to calving } & \multirow[b]{2}{*}{$\mathrm{SE}^{2}$} & \multicolumn{4}{|c|}{$\frac{\text { Fixed effect }}{3}$} \\
\hline & & $-10^{4}$ & 3 & 9 & 16 & 44 & & $\mathrm{~T}$ & $\mathrm{D}$ & $\mathrm{S}$ & $\mathrm{T} \times \mathrm{D}$ \\
\hline \multirow[t]{2}{*}{$A C S S 1$} & RAP & -0.07 & -0.09 & -0.11 & -0.02 & -0.13 & 0.040 & 0.29 & 0.26 & $<0.01$ & 0.45 \\
\hline & GRAD & -0.12 & -0.23 & -0.22 & -0.10 & -0.09 & & & & & \\
\hline PPARa & RAP & 0.74 & 0.67 & 0.69 & 0.74 & 0.70 & 0.041 & 0.02 & 0.96 & $<0.01$ & 0.13 \\
\hline$H M G C S 1$ & GRAD & 0.87 & 0.87 & 0.84 & 0.87 & 0.82 & & & & & \\
\hline \multirow[t]{2}{*}{$H M G C S 2$} & RAP & 2.28 & 2.35 & 2.37 & 2.43 & 2.34 & 0.037 & 0.38 & 0.10 & $<0.01$ & 0.56 \\
\hline & GRAD & 2.19 & 2.36 & 2.35 & 2.32 & 2.35 & & & & & \\
\hline \multirow[t]{2}{*}{$B D H 1$} & RAP & 1.33 & 1.42 & 1.42 & 1.48 & 1.40 & 0.033 & 0.19 & 0.10 & $<0.01$ & 0.44 \\
\hline & GRAD & 1.27 & 1.37 & 1.39 & 1.38 & 1.38 & & & & & \\
\hline \multirow[t]{2}{*}{ BDH2 } & RAP & 0.10 & 0.11 & 0.14 & 0.21 & 0.08 & 0.035 & 0.04 & 0.36 & $<0.01$ & 0.16 \\
\hline & GRAD & 0.02 & 0.01 & 0.07 & 0.07 & 0.03 & & & & & \\
\hline
\end{tabular}

${ }^{1}$ Expression was normalized against keratin-6.

${ }^{2}$ Standard error for LSM by sampling day; $\mathrm{n}=12$.

${ }^{3} \mathrm{~T}=$ treatment, $P$-value for treatment period (d 9 to 44$) ; \mathrm{D}=$ sampling day, $P$-value for pretreatment and treatment period $(\mathrm{d}-10$ to 44$) ; \mathrm{S}=$ sampling site within the rumen; $\mathrm{T} \times \mathrm{D}=$ interaction between treatment and sampling day, $P$-value for treatment period (d 9 to 44 ).

${ }^{4}$ Group GRAD: $\mathrm{n}=5,1$ cow had no measurement at $\mathrm{d}-10$ due to early calving.

an increase of $32 \%$ compared with $3 \mathrm{~d}$ and $44 \mathrm{~d}$ pp $(P$ $<0.001)$. Expression of DRA was neither affected by treatment $(P=0.37)$ nor by the treatment and sam- pling day interaction $(P=0.96)$. Expression of NHE2 was affected by sampling day $(P<0.01)$ and increased by $113 \%$ from 3 to $16 \mathrm{~d}$ pp $(P<0.001)$, remaining

Table 7. Least squares means of $\log _{10}$-transformed expression of genes in the rumen papillae associated with VFA metabolism during the dry period experiment for the control (no concentrate during the dry period; $\mathrm{CON}, \mathrm{n}=5$ ) and supplemental concentrate treatment $(3.0 \mathrm{~kg}$ of $\mathrm{DM} / \mathrm{d}$ concentrate during the dry period; SUP, $\left.\mathrm{n}=4^{1}\right)^{2}$

\begin{tabular}{|c|c|c|c|c|c|c|c|c|c|c|c|c|c|}
\hline \multirow[b]{3}{*}{ Gene } & \multirow[b]{3}{*}{ Group } & \multicolumn{7}{|c|}{ Sampling day relative to calving } & \multirow[b]{3}{*}{$\mathrm{SE}^{3}$} & \multirow{2}{*}{\multicolumn{4}{|c|}{$\frac{\text { Fixed effect }}{4}$}} \\
\hline & & \multirow[b]{2}{*}{-28} & \multirow[b]{2}{*}{-18} & \multirow[b]{2}{*}{-8} & \multirow[b]{2}{*}{3} & \multirow[b]{2}{*}{17} & \multirow[b]{2}{*}{31} & \multirow[b]{2}{*}{45} & & & & & \\
\hline & & & & & & & & & & $\mathrm{T}$ & $\mathrm{D}$ & $\mathrm{S}$ & $\mathrm{T} \times \mathrm{D}$ \\
\hline \multirow[t]{2}{*}{$A C S S 1$} & $\mathrm{CON}$ & 0.07 & -0.05 & -0.01 & -0.14 & -0.09 & -0.05 & -0.08 & \multirow{2}{*}{0.046} & $<0.01$ & 0.24 & $<0.01$ & 0.76 \\
\hline & SUP & 0.07 & 0.15 & 0.13 & -0.01 & 0.05 & 0.01 & 0.02 & & & & & \\
\hline PPARa & $\mathrm{CON}$ & 0.45 & 0.42 & 0.46 & 0.52 & 0.47 & 0.46 & 0.46 & 0.054 & $<0.01$ & 0.99 & $<0.01$ & 0.97 \\
\hline$H M G C S 1$ & SUP & 0.77 & 0.92 & 0.90 & 0.84 & 0.87 & 0.74 & 0.80 & & & & & \\
\hline \multirow[t]{2}{*}{ HMGCS2 } & $\mathrm{CON}$ & 2.24 & 2.23 & 2.14 & 2.40 & 2.28 & 2.29 & 2.28 & 0.039 & 0.78 & 0.01 & $<0.01$ & 0.63 \\
\hline & SUP & 2.22 & 2.29 & 2.23 & 2.42 & 2.33 & 2.17 & 2.26 & & & & & \\
\hline \multirow[t]{2}{*}{$B D H 1$} & $\mathrm{CON}$ & 1.24 & 1.20 & 1.15 & 1.33 & 1.18 & 1.20 & 1.22 & 0.042 & 0.03 & 0.16 & $<0.01$ & 0.83 \\
\hline & SUP & 1.28 & 1.35 & 1.27 & 1.39 & 1.31 & 1.20 & 1.26 & & & & & \\
\hline \multirow[t]{2}{*}{ BDH2 } & $\mathrm{CON}$ & -0.18 & -0.22 & -0.20 & -0.15 & -0.21 & -0.20 & -0.18 & 0.029 & $<0.01$ & 0.36 & $<0.01$ & 0.54 \\
\hline & SUP & -0.09 & -0.02 & -0.10 & 0.00 & -0.09 & -0.14 & -0.12 & & & & & \\
\hline
\end{tabular}

${ }^{1}$ Group SUP: $\mathrm{n}=4,1$ cow was removed from the experiment.

${ }^{2}$ Expression was normalized against keratin-6.

${ }^{3}$ Standard error for LSM by sampling day; $\mathrm{n}=9$.

${ }^{4} \mathrm{~T}=$ treatment; $\mathrm{D}=$ sampling day; $\mathrm{S}=$ sampling site within the rumen; $\mathrm{T} \times \mathrm{D}=$ interaction between treatment and sampling day. 
Table 8. Least squares means of $\log _{10}$-transformed expression of genes associated with VFA absorption, VFA metabolism, and apoptosis in rumen papillae obtained from 3 different sites for the lactation experiment (treatment comprised either a rapid or gradual rate of increase of concentrate allowance postpartum) and the dry period experiment (treatment comprised either supplemental concentrate during the last 4 wk of the dry period or no concentrate supplement) ${ }^{1}$

Sampling site in the rumen ${ }^{2,3}$

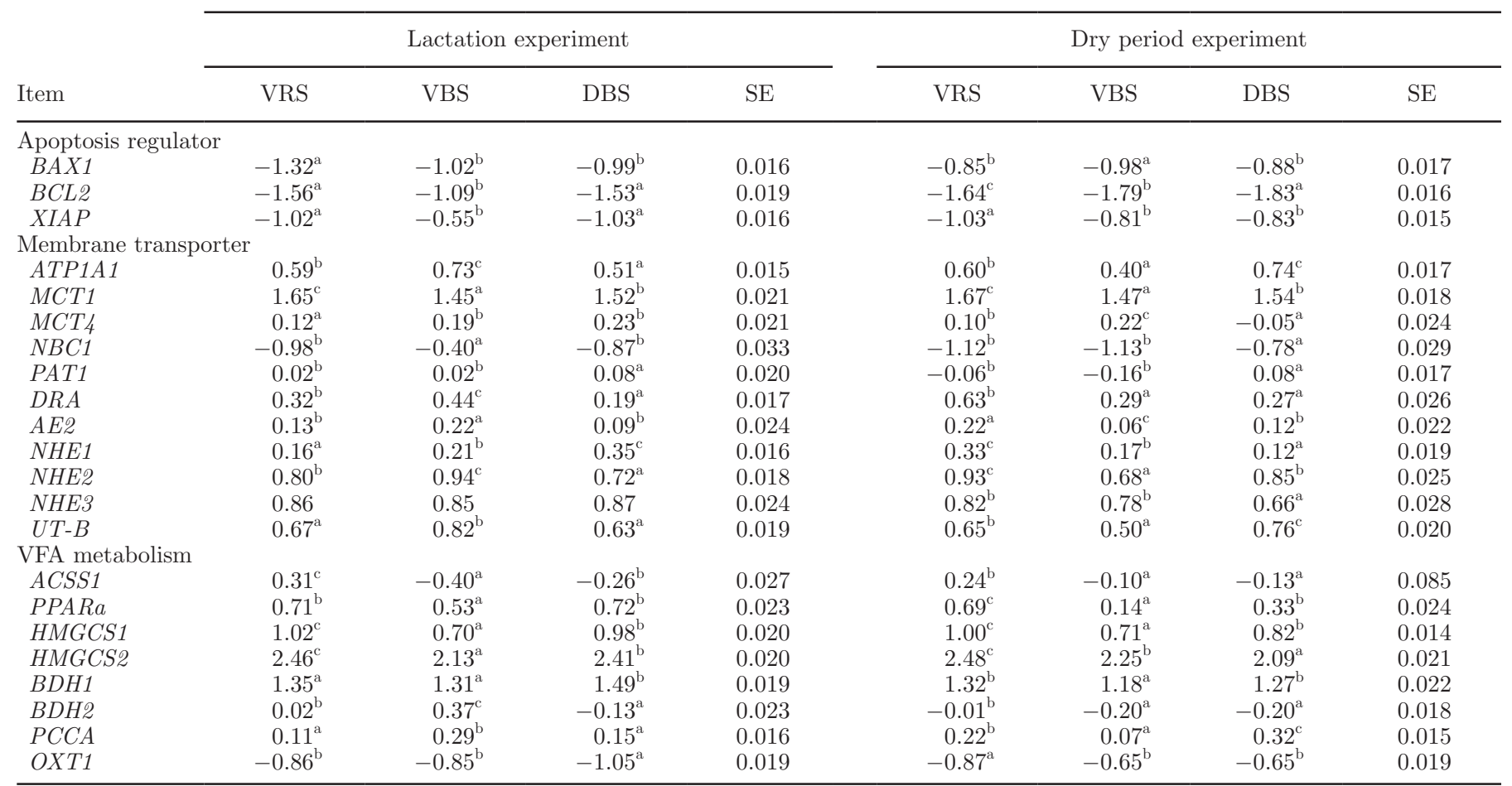

\footnotetext{
${ }^{\mathrm{a}-\mathrm{c}}$ Significance of differences in LSM of the site within gene and experiment, $P<0.05$.

${ }^{1}$ Expression was normalized against keratin-6.

${ }^{2}$ Fixed effect for site was $P<0.01$ for all genes except NHE3 $(P=0.78)$ during the lactation experiment.

${ }^{3} \mathrm{VRS}=$ ventral rumen sac; VBS $=$ ventral blind rumen sac; DBS $=$ dorsal blind rumen sac.
}

similar for 16 and $44 \mathrm{~d}$ pp $(P=0.82)$. The NHE2 content was not affected by treatment $(P=0.74)$ or interaction between treatment and sampling day $(P=$ 0.44). Expression of ATP1A1 was affected by an interaction between treatment and sampling day $(P \leq$ 0.03). For RAP, ATP1A1 tended to decrease from 3 to $16 \mathrm{~d}$ pp $(P=0.06)$, whereas for GRAD a decrease was observed from 3 to $16 \mathrm{~d}$ pp $(P<0.01)$. The expression of ATP1A1 was similar at 16 and $44 \mathrm{~d} \mathrm{pp}(P \geq 0.18)$ for both RAP and GRAD. Expression of ATP1A1 at 44 d pp was greater for RAP compared with GRAD $(P=$ 0.01). The expression of PCCA, a subunit of propionylCoA carboxylase involved in mitochondrial metabolism of propionate, was affected by sampling day only $(P$ $=0.02)$ and increased from 3 to $16 \mathrm{~d}$ pp by $21 \%(P<$ 0.01 ), whereas PCCA expression at $44 \mathrm{~d}$ pp did not differ from either 3 or $16 \mathrm{~d} p p(P \geq 0.14)$. The expression of PCCA with RAP increased from 3 to $16 \mathrm{~d}$ pp $(P$ $<0.01)$ and decreased from 16 to $44 \mathrm{~d}$ pp $(P=0.05)$, whereas we observed no changes in the expression with $\operatorname{GRAD}(P \geq 0.34)$.

\section{Correlation Between Gene and Protein Expression Levels}

The relationship between gene and protein expression of MCT1, DRA, NHE2, and ATP1A1 (Figure 3) was not significant $(P \geq 0.32)$. For PCCA, a significant $(P$ $=0.02)$ but weak $\left(\mathrm{R}^{2}=0.16\right)$ correlation was observed.

\section{DISCUSSION}

The present experiments provide a unique combination of results on morphological changes of the rumen papillae and in vivo changes in fractional VFA absorption and production rate, and the concomitant changes in expression of selected genes involved in VFA absorption, VFA metabolism, and associated with rumen epithelium cell apoptosis. Several of the genes examined were affected by the transition from the dry period ration to the lactation ration, or by the treatments applied during either the dry period or early lactation. However, an interaction between sampling day and treatment was only observed for a few genes. 

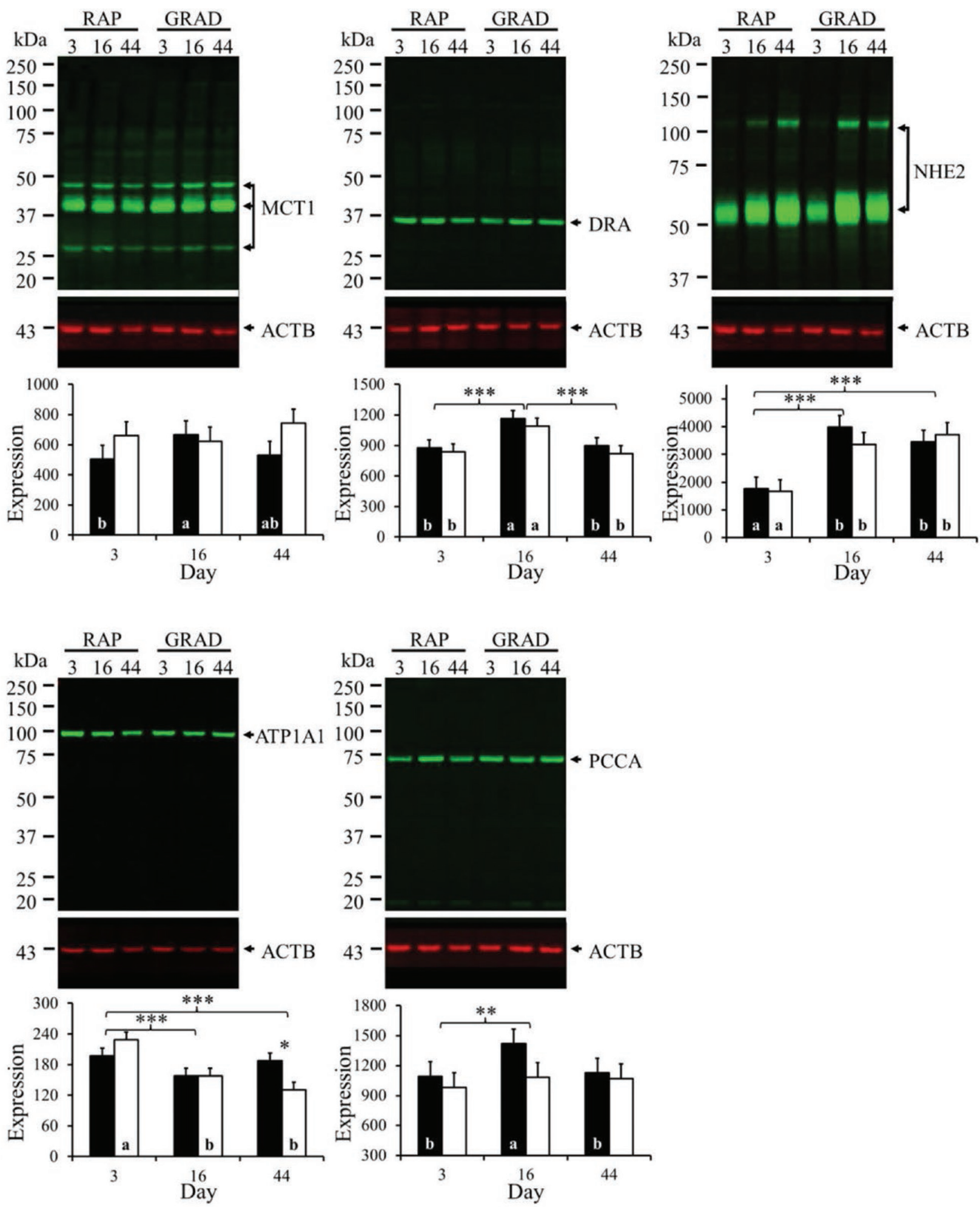

Figure 2. Western blot rumen epithelial protein expression of VFA transporters DRA and MCT1, the $\mathrm{Na}^{+} / \mathrm{H}^{+}$antiporter NHE2, ATP-driven $\mathrm{Na}^{+} / \mathrm{K}^{+}$exchanger ATP1A1, and propionate metabolism-associated PCCA with a rapid rate of increase (1.0 kg of DM/d; RAP) of concentrate allowance (black bar; $\mathrm{n}=6$ ) and gradual rate of increase $(0.25 \mathrm{~kg}$ of $\mathrm{DM} / \mathrm{d}$; GRAD) of concentrate allowance (white bar; $\mathrm{n}=6)$ treatments. Treatments started at $4 \mathrm{~d}$ postpartum, with maximum daily concentrate allowance increasing to $10.9 \mathrm{~kg}$ of DM/d for both RAP and GRAD. Values represent LSM $\pm \mathrm{SE} ;{ }^{*} P<0.05,{ }^{* *} P<0.01,{ }^{* * *} P<0.001$, significance of difference in LSM by day (bars indicate respective days), or RAP or GRAD for the same sampling day. Different letters $(\mathrm{a}, \mathrm{b})$ indicate differences between days within treatment group, $P<0.05$. Expression is normalized against $\beta$ actin (ACTB). Color version available online. 

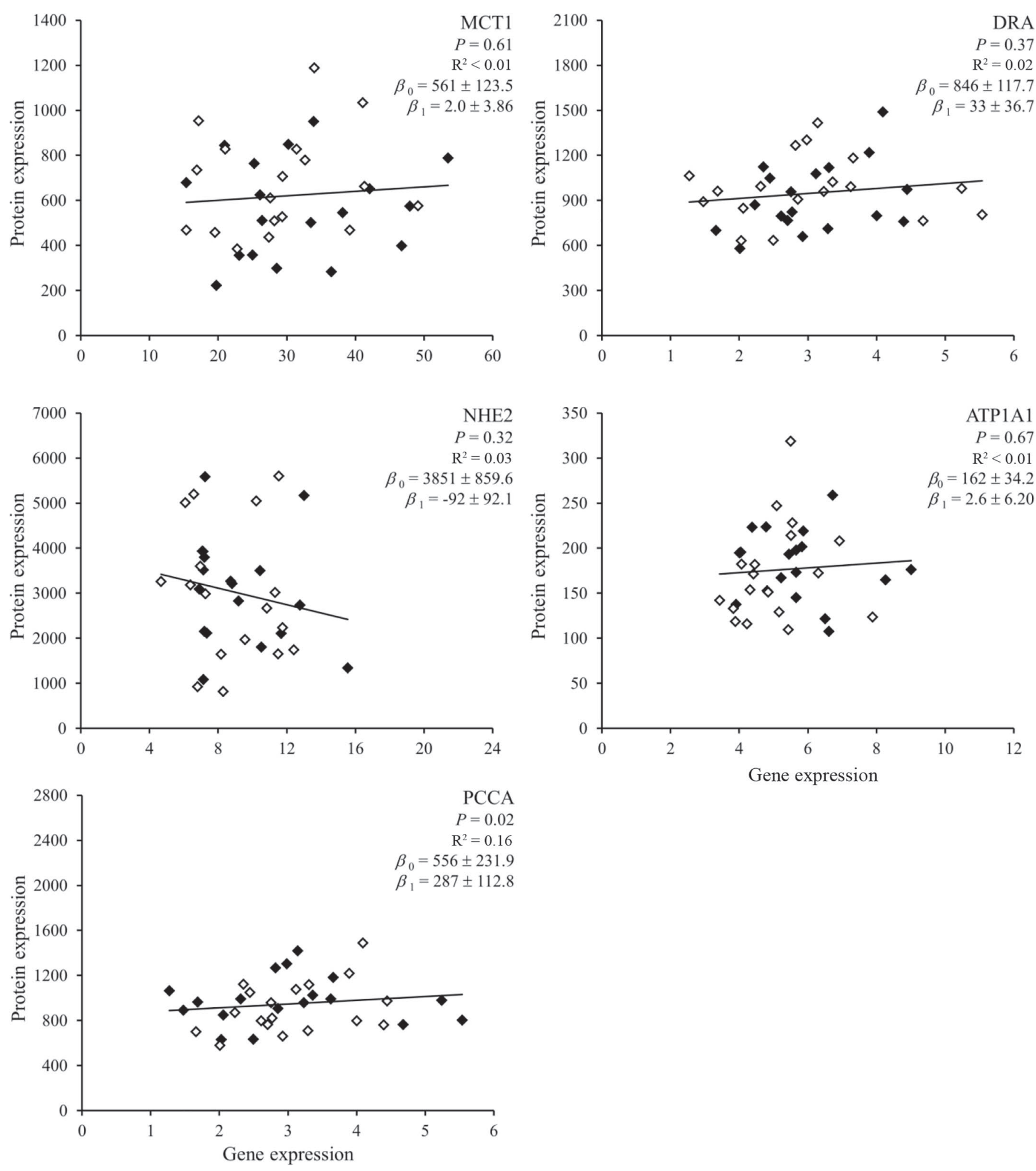

Figure 3. Relationship between gene and protein expression in rumen papillae collected from the ventral blind rumen sac during the lactation experiment for a rapid $(1.0 \mathrm{~kg}$ of $\mathrm{DM} / \mathrm{d} ; \bullet, \mathrm{n}=6)$ and gradual $(0.25 \mathrm{~kg}$ of $\mathrm{DM} / \mathrm{d} ; \diamond, \mathrm{n}=6)$ rate of increase of concentrate allowance postpartum. Gene and protein expression data are not transformed. Solid line represents linear regression of all data points; $b_{0}=$ intercept \pm $\mathrm{SE}$, and $b_{1}=$ slope of the regression equation \pm SE. Protein expression was normalized against $\beta$-actin (ACTB). Gene expression was normalized against keratin-6 (KRT6). 
Generally, more lactation stage-related effects on gene expression were observed for the dry period experiment when compared with the lactation experiment, which might be explained by the greater number of sampling days ( 8 vs. 5 ) and broader timespan ( $28 \mathrm{~d}$ ap to $45 \mathrm{~d}$ pp vs. $10 \mathrm{~d}$ ap to $44 \mathrm{~d} \mathrm{pp}$ ) under investigation. The level of expression of the genes compares well between experiments, indicating consistency in methodology and allowing for direct comparison of the experiments, but differed between sites for nearly all genes. The ventral part of the rumen is thought to be primarily responsible for the absorption of VFA (Von Engelhardt and Hales, 1977; Storm et al., 2011). It could, therefore, be hypothesized that the VRS, and especially the VBS, would have a greater level of expression of genes associated with VFA transport and metabolism than the DBS. Whereas this was generally the case for the lactation experiment, no such pattern was observed for the dry period experiment. When comparing the experiments, there also appears to be little consistency in ranking of the expression levels between sites.

\section{Expression of Genes Associated with Apoptosis}

Generally, tissue proliferation coincides with both an increase in mitosis and apoptosis (Raab et al., 1998; Gui and Shen, 2016). Mitosis in the rumen epithelium has been shown to increase in response to a higher VFA concentration (Sakata and Yajima, 1984). For apoptosis, the effects of VFA appear to depend on type of VFA. Propionate stimulates mitosis and simultaneously increases rate of apoptosis, which might be interpreted as a sign of extensive tissue remodeling (Mentschel et al., 2001). However, butyrate appears to suppress an increase in apoptosis rate while eliciting a similar increase in mitosis rate as propionate, possibly explaining increased tissue growth with butyrate compared with propionate (Mentschel et al., 2001). Observations (not reported) showed that immunochemical staining against proliferating cell nuclear antigen in histological sections did not differ between treatments.

In the present experiments, the concentration and molar proportions of propionate and butyrate increased after calving, as well as the production rates of the VFA, associated with a large increase in papillae surface area (Dieho et al., 2016a,b, 2017). However, the mRNA expression levels of $B C L 2$ and XIAP, both inhibitors of apoptosis, and the mRNA expression of apoptotic activator $B A X 1$ were not affected by the transition from the dry period into lactation for both experiments. These observations suggest that after calving the suppressive effects of the increased butyrate concentration on the apoptosis rate are balanced against the stimulating effect of increased propionate concentration on apop- tosis rate. In the lactation experiment, the propionate concentration, but not the butyrate concentration, was higher in RAP than GRAD at 9 and $16 \mathrm{~d}$ pp (Dieho et al., 2016a), whereas daily propionate, but not butyrate, production was greater at $16 \mathrm{~d}$ pp in RAP than GRAD (Dieho et al., 2016b). In line with the greater propionate concentration and production, mRNA expression of $B A X 1$ tended to be greater in RAP than GRAD, which suggests a greater apoptosis rate. The papillae surface area increased faster in RAP than GRAD, which suggests an even greater increase in mitosis rate and extensive remodeling of the epithelium (Gui and Shen, 2016). However, mRNA expression of BAX1 was already numerically greater for RAP than GRAD during the dry period, indicating that the observed treatment effect might be due to inherent differences between the groups. Examining the BCL2/BAX ratio did not reveal an effect of sampling day or an interaction between sampling day and treatment. A greater ratio would indicate a suppression of apoptosis, which would be expected after calving in for both treatments groups compared with the dry period, with a further increase in RAP compared with GRAD.

In the dry period experiment, propionate and, particularly, butyrate concentration were higher in SUP than CON at 18 and $8 \mathrm{~d}$ pp. However, the greater mRNA expression of $B A X 1$ and the tendency toward lower expression of BCL2 in SUP compared with CON indicated increased apoptosis rate, which would contradict expectations based on the greater butyrate concentration (Mentschel et al., 2001). In conclusion, it is difficult to consistently explain the observed changes in papillae surface area from the changes in expression of apoptosis-related genes. This suggests that the growth of papillae in transition dairy cattle is primarily the result of fluctuations in mitosis rate while maintaining apoptosis rate at a rather stable level. In contrast to the lactation experiment, the BCL2/BAX ratio appeared affected by the concentrate supplementation. However, differences persisted into lactation despite the similar feed intake for SUP and CON. Moreover, as in the lactation experiment, the BCL2/BAX ratio was not affected by sampling day and did not increase after calving despite the observed increases in papillae surface area (Dieho et al., 2017). These ambiguous results suggest that care should be taken interpreting measures such as the BCL2/BAX ratio with regard to morphological changes.

\section{Expression of Genes Associated with VFA Absorption, Intracellular $\mathrm{pH}$, and Urea Transport}

It was hypothesized that the large increase in daily VFA production during lactation would increase the 
mRNA expression of genes associated with VFA transport, maintenance of intracellular $\mathrm{pH}$ (Penner et al., 2009), and, due to greater protein intake, urea transport. In contrast to our hypothesis, effects of sampling day were not observed during the lactation experiment, except for NCB1, which increased after calving. In contrast, expression of genes generally decreased after calving during the dry period experiment. Assuming that changes in gene expression coincide with equivalent effects on protein expression and function, this suggests that, per unit of surface area, the capacity for transport is not affected (lactation experiment) or decreases (dry period experiment). This suggestion implies that the large increase in $k_{\mathrm{a}}$ VFA observed postpartum is mainly the result from the increase in papillae surface area. In contrast to this relationship between $k_{\mathrm{a}} \mathrm{VFA}$ and papillae surface in the transition period, increases in papillae surface area resulting from dietary treatment (most notably at $16 \mathrm{pp}$ in the lactation experiment and at 18 and $8 \mathrm{~d}$ ap during the dry period experiment) were not associated with elevated $k_{\mathrm{a}} \mathrm{VFA}$. The absence of such an association suggests involvement of extra-epithelial processes, such as in epithelial blood flow (Storm et al., 2011). These results contrast with earlier findings from in vitro measurements, which suggested an increase in VFA absorption capacity independent of surface area (Sehested et al., 2000; Etschmann et al., 2009; Schurmann et al., 2014).

Although the importance of protein-mediated VFA uptake relative to passive diffusion is still uncertain, several pathways have been established (Aschenbach et al., 2011). Two major isoforms of monocarboxylate transporters (MCT1, Kirat et al., 2006; Graham et al., 2007; MCT4, Kirat et al., 2007) have been demonstrated in the rumen epithelium. Results from the present experiments show that mRNA expression of MCT1 is markedly greater than MCT4 expression, confirming earlier reports on transition dairy cattle (Minuti et al., 2015). The transition from the dry period to lactation only increased MCT1 mRNA expression at $3 \mathrm{~d}$ pp in the dry period experiment. In contrast, Minuti et al. (2015) observed a tendency for increase in MCT1 from $10 \mathrm{~d}$ ap to $28 \mathrm{~d}$ pp. Other experiments have likewise reported conflicting results on the mRNA expression of MCT1. Upregulation of MCT1 was reported in association with a large increase in grain content of the ration (Metzler-Zebeli et al., 2013), whereas dietary NFC source (starch, sugar, or lactose; Oba et al., 2015) and animal susceptibility to acidosis (Schlau et al., 2012) were not associated with differences in MCT1 expression. Protein expression of MCT1 increased from 3 to $16 \mathrm{~d}$ pp with RAP, but not with GRAD. Although mRNA expression of $M C T 1$ was not affected by treatment or day in the lactation experiment, the absence of changes in mRNA expression from 3 to $44 \mathrm{~d}$ pp with GRAD, and the numerical increase in mRNA expression from 3 to $16 \mathrm{~d}$ pp followed by a decline again to $44 \mathrm{~d}$ pp are in line with the observed changes in MCT1 protein expression. The enhanced protein expression of MCT1 at $16 \mathrm{~d}$ pp might indicate a greater capacity for export of VFA from the epithelium to the blood, an adaptation in line with the (numerically) greater VFA production rate (Dieho et al., 2016b). The subsequent numerical decrease in transport capacity per unit of surface area by $44 \mathrm{~d}$ pp might be compensated by the larger papillae surface area at $44 \mathrm{~d} \mathrm{pp}$; however, the greater expression of MCT1 did not affect the $k_{\mathrm{a}}$ VFA in RAP compared with GRAD (Dieho et al., 2016b).

As exchangers of $\mathrm{VFA}^{-} / \mathrm{HCO}_{3}{ }^{-}$, the apically located DRA and PAT1 (Bilk et al., 2005) play a central role in the absorption of dissociated VFA and buffering of the rumen fluid (Penner et al., 2011; Aschenbach et al., 2011), whereas the basally located $\mathrm{Na}^{+} / \mathrm{HCO}_{3}{ }^{-}$cotransporter NBC1 plays a role in replenishing the epithelial $\mathrm{HCO}_{3}{ }^{-}$pool (Connor et al., 2010). Oba et al. (2015) reported the mRNA expression of PAT1 to be affected by NFC source (starch, sugar, or lactose), and the large changes in NFC intake due to lactation stage or treatment in the present experiment were therefore expected to induce effects on PAT1 mRNA expression. However, PAT1 was not affected by lactation stage either experiment, but mRNA expression of PAT1 tended to be higher with the rapid compared with the gradual concentrate increase in the lactation experiment. In case of $D R A$ mRNA, results from the 2 experiments were not consistent; mRNA expression of $D R A$ did not change after calving in the lactation experiment, but decreased after calving in the dry period experiment, despite cows receiving similar rations in both experiments. The NFC source did not affect expression of DRA in the experiment reported by Oba et al. (2015), which appears to contradict the results from the dry period experiment. Although mRNA expression of $D R A$ was not affected by sample day in the lactation period experiment, the protein expression of DRA in the lactation experiment indicates that the temporary upregulation at $16 \mathrm{~d} p \mathrm{pp}$ occurred at the protein translation level. The subsequent decrease in $\mathrm{VFA}^{-} / \mathrm{HCO}_{3}{ }^{-}$exchange capacity per unit of surface area by $44 \mathrm{~d}$ pp might be due to the larger papillae surface area at $44 \mathrm{~d}$ pp.

The $\mathrm{Na}^{+} / \mathrm{H}^{+}$exchanger isoforms 1 to 3 play a central role in the regulation of intracellular $\mathrm{pH}$ (Zachos et al., 2005). The NHE1 are concentrated in the stratum granulosum, whereas NHE2 is located in the cytosol in all cell layers, arguably as a form of functional reserve (Graham et al., 2007). During both experiments, similar mRNA expression levels were found for NHE2 and NHE3, which were expressed at $\sim 4$ times the 
level of NHE1 (before $\log _{10}$ transformation). However, Etschmann et al. (2009) reported that NHE1 was by far the most highly expressed of the NHE in rumen epithelial cell cultures from sheep, which might reflect in vitro or in vivo differences. In our experiments (Dieho et al., 2016a, 2017), the treatments, and particularly the transition into lactation, increased starch and sugar intake. Still, NHE1, NHE2, and NHE3 were not affected by sampling day or treatment during the lactation experiment, whereas during the dry period experiment mRNA expression of NHE2 and NHE3 decreased after calving. This contrasts with Oba et al. (2015), who reported an increase in mRNA expression of NHE1 and NHE2 in rumen epithelium of dry nongravid dairy cows upon daily ruminal dosing of $3.0 \mathrm{~kg}$ of DM of sucrose or lactose compared with starch. Similar to DRA, expression of NHE2 protein was greater at 16 and $44 \mathrm{~d}$ pp compared with $3 \mathrm{~d}$ pp, without concomitant changes in gene expression. The greater protein expression of NHE2 suggests that the rumen epithelium increases its back-up capacity for maintaining intracellular $\mathrm{pH}$ during lactation (Graham et al., 2007), where rumen $\mathrm{pH}$ is known to fluctuate to a greater extent than during the dry period.

In the dry period experiment, we observed a peak in the mRNA expression of $U T-B$ at $3 \mathrm{~d}$ pp, which might be associated with the abrupt transition to the lactation ration (higher $\mathrm{CP}$ than dry period ration) on the day of calving. Numerically, a similar increase may be noticed between $10 \mathrm{~d}$ ap to $3 \mathrm{~d}$ pp during the lactation experiment, where cows were also abruptly transitioned to a similar lactation ration. During the first weeks of lactation concentrate allowance, and consequently CP intake, increased further, but did not affect $U T-B$ expression; previous results are likewise ambiguous. In transition dairy cattle, Minuti et al. (2015) found similar UT-B expressions between $14 \mathrm{~d}$ ap and $10 \mathrm{~d}$ pp, which thereafter increased at $28 \mathrm{~d}$ pp. Simmons et al. (2009) demonstrated a greater expression of $U T-B$ for a concentrate-rich ration compared with a forage rich ration (both 13\% CP) in Limousine steers, whereas Røjen et al. (2011) did not find an effect of dietary CP content (13 vs. $17 \%$ ) on $U T-B$ expression in dairy cows.

The ATP-driven $\mathrm{Na}^{+} / \mathrm{K}^{+}$exchanger, of which ATP1A1 is a subunit, maintains low intracellular $\mathrm{Na}^{+}$ and high $\mathrm{K}^{+}$concentrations, thereby providing a driving force for several exchangers and co-transporters (Aschenbach et al., 2011). The absence of changes in ATP1A1 mRNA expression in the lactation experiment is in line with the general absence of effects observed for the other transporters, most notably the NHE. Similarly, the greater expression levels for ATP1A1 in SUP in the dry period experiment corresponded with the generally greater mRNA expression levels of the other transport associated genes, including the NHE. However, the apparent effect of treatment on ATP1A1 mRNA expression at 18 and $8 \mathrm{~d}$ ap is at odds with the lack of effect of the transition into lactation, and also with the outcome of earlier experiments, which did not show an increase in mRNA expression of ATP1A1 with increased concentrate feeding (Penner et al., 2009; Metzler-Zebeli et al., 2013). The observed decrease in expression of ATP1A1 protein during the lactation, whereas no concomitant change in mRNA expression of ATP1A1 was observed, suggests that protein expression is regulated after transcription. The lower expression of ATP1A1 protein suggests an alteration in rumen sodium homeostasis after calving by decreasing the capacity for $\mathrm{Na}^{+} / \mathrm{K}^{+}$exchange.

During the dry period experiment, the mRNA expression of ATP1A1, MCT4, NBC1, DRA, and NHE3 was, on average, greater for SUP than CON. This suggests a positive effect of concentrate supplementation during the dry period on rumen buffering and VFA uptake capacity. Moreover, it suggests that such changes are carried over into lactation. However, no differences between treatments in $k_{\mathrm{a}} \mathrm{VFA}$ were observed at any moment during the experiment (Dieho et al., 2017), indicating that caution is warranted when basing conclusions on tissue function on gene expression results. In addition, as discussed earlier, changes in gene and protein expressions generally did not correspond, and protein expression data did also not consistently correspond with the observed $k_{\mathrm{a}} \mathrm{VFA}$, again indicating that caution is warranted when interpreting such data. It is also hard to explain why the relatively limited effect of supplemental concentrate during the dry period experiment on feed intake, rumen VFA production, and rumen fluid composition (Dieho et al., 2017) would have a significant and long-lasting effect on gene expressions, whereas the much larger differences in feed intake, VFA production, and rumen fluid composition due to transition into lactation had none. It seem more plausible that the results reflect an undesired, unbalanced distribution of cows, as was observed for the papillae surface area during this experiment (Dieho et al., 2017). Such inherent differences in gene expression, despite feeding similar rations, have been suggested previously (Schlau et al., 2012).

\section{Expression of Genes Associated with VFA Metabolism}

Increases in VFA production were hypothesized to coincide with increases in mRNA expression of genes associated with rumen epithelial metabolism (Penner et al., 2011). In our experiments, VFA production increased after calving due to an increase in FOM intake 
(Dieho et al., 2016b, 2017). However, the observed large production of VFA had only a minor effect on the expression of genes associated with epithelial metabolism of VFA. The absence of pronounced effects on mRNA expression might in part be explained by the increase in tissue mass associated with the increase in papillae size.

During both experiments, the treatments had pronounced effects on the composition of the rumen fluid (Dieho et al., 2016a, 2017). The concentration of butyrate was greater at 18 and $8 \mathrm{~d}$ ap and $3 \mathrm{~d}$ pp for SUP than CON, whereas both the propionate production and concentration was greater for RAP than GRAD at $16 \mathrm{~d}$ pp. The mitochondrial enzyme HMGCS2 and the 3-hydroxybutyrate dehydrogenases BDH1 and BDH2 catalyze the synthesis of BHB (Lane and Jesse, 1997; Penner et al., 2011; Oba et al., 2015), whereas OXCT1 is associated with catabolism of ketone bodies. Butyrate is considered the main substrate for ketogenesis (Kristensen and Harmon, 2004). Therefore, an upregulation of the corresponding genes was expected due increased butyrate availability after calving for both experiments and during the dry period for SUP. Likewise, PCCA, involved in the metabolism of propionate, was also expected to be upregulated after calving due to increased production of propionate, particularly for RAP. However, only mRNA expression of HMGCS1 but not HMGCS2 appears to reflect the temporarily greater butyrate concentrations in SUP at 18 and $8 \mathrm{~d}$ ap compared with CON. The general absence of treatment and lactation stage effects on gene expression in the present experiments is supported by results from trials where cows were fed high concentrate rations for 3 to 4 wk (Penner at al., 2009; Steele et al., 2012). No changes in mRNA expression were observed for HMGCS2 and PPARa with a weekly sampling regimen (Steele et al., 2012), nor were changes observed for HMGCS2, PPARa, BDH1, BDH2, ACSS1, and $P C C A$ with sampling after 4 wk of feeding a highconcentrate versus a high-forage ration (Penner et al., 2009). It should be noted that during the dry period experiment, consistent differences between SUP and CON in ACSS1, PPARa, BDH1, BDH2, and OXCT1 throughout the experimental period were observed. As discussed previously, these consistent patterns suggest inherent differences between individuals in the dry period experiment.

Expression of HMGCS2 is under the control of PPARa (Steele et al., 2011); thus, the greater mRNA expression of PPARa in SUP is at odds with the lack of a treatment effect on mRNA expression of HMGCS2. Another contrast between the expressions of these genes has been reported by Minuti et al. (2015), who observed an increase in HMGCS2 but not PPARa. The greater levels of mRNA expression of HMGCS2 and
$B D H 2$ than $P C C A$ agree with the extensive metabolism of butyrate and limited metabolism of propionate by the epithelium (Kristensen and Harmon, 2004), which corresponds to earlier studies (Naeem et al., 2012; Minuti et al., 2015). In contrast to the absence of changes in mRNA expression of $P C C A$ during the lactation experiment, expression of PCCA protein was greater for RAP compared with GRAD at d $16 \mathrm{pp}$, which is in line with the elevated propionic acid concentration and production with RAP, suggesting regulation at the protein translation level.

\section{Correlation Between Gene and Protein Expression Levels}

Although it is generally recognized that changes in gene expression levels do not necessarily indicate similar changes in protein expression, previous studies by Penner et al. (2009), Schlau et al. (2012), and Yang et al. (2012), among others, on gene expression in rumen epithelium assume that greater gene expression levels represent equivalent functional changes in the relevant characteristics. Few studies report the relationship between gene and protein expression levels in rumen papillae, although the explanatory power of gene expression level alone without concomitant protein expression or functional measurements is known to be limited (Connor et al., 2010). To further examine the validity of the assumption that gene expression is related to protein expression, the correlation between the gene and protein expression of MCT1, DRA, NHE2, ATP1A1, and PCCA in the ventral blind rumen sac was determined. The nonsignificant relationship between gene and protein expressions of MCT1, DRA, NHE2 and ATP1A1, and significant but weak correlation for PCCA suggest that, at least in the fully developed rumen, care should be taken when inferring protein expression level (or function) from gene expression data.

\section{CONCLUSIONS}

The present results show minor changes in the expression of genes associated with rumen epithelial transport and metabolism of VFA in dairy cows during the transition period. The results, therefore, indicate that the capacity for VFA absorption and metabolism of the epithelium changes little per unit of surface area, and that the major response to the increase in daily VFA production after calving is an increase in papillae surface area. Furthermore, expression of apoptosis-related genes was not affected by the transition into lactation; this indicates that it is not a not downregulation of apoptosis rate that drives papillae tissue growth. In contrast to the expression at the gene level, expression 
of selected proteins involved in the absorption and metabolism of VFA in rumen epithelial tissue was affected of VFA in rumen epithelial tissue was affected by the changes in diet, $\mathrm{pH}$, and VFA during early lactation. The differences between gene and protein expression and the generally nonsignificant and weak correlation between the examined gene and protein expression levels indicate that care must be taken when interpreting results obtained at either level.

\section{ACKNOWLEGDMENTS}

The authors acknowledge the Dairy Campus staff (Lelystad, the Netherlands) for their technical support during the experiments. The authors acknowledge the financial support of the Product Board Animal Feed (Zoetermeer, the Netherlands) and Dutch Dairy Board (Zoetermeer, the Netherlands).

\section{REFERENCES}

Andersen, C. L., J. L. Jensen, and T. F. Ørntoft. 2004. Normalization of real-time quantitative reverse transcription-PCR data: A model-based variance estimation approach to identify genes suited for normalization, applied to bladder and colon cancer data sets. Cancer Res. 64:5245-5250. https://doi.org/10.1158/0008-5472. CAN-04-0496.

Aschenbach, J. R., G. B. Penner, F. Stumpff, and G. Gäbel. 2011. Ruminant nutrition symposium: Role of fermentation acid absorption in the regulation of ruminal pH. J. Anim. Sci. 89:1092-1107. https://doi.org/10.2527/jas.2010-3301.

Ballhausen, D., L. Mittaz, O. Boulat, L. Bonafé, and O. Braissant. 2009. Evidence for catabolic pathway of propionate metabolism in CNS: expression pattern of methylmalonyl-CoA mutase and propionyl-CoA carboxylase alpha-subunit in developing and adult rat brain. Neuroscience 164:578-587. https://doi.org/10.1016/j. neuroscience.2009.08.028.

Bannink, A., W. J. J. Gerrits, J. France, and J. Dijkstra. 2012. Variation in rumen fermentation and the rumen wall during the transition period in dairy cows. Anim. Feed Sci. Technol. 172:80-94. https://doi.org/10.1016/j.anifeedsci.2011.12.010.

Bergman, E. N. 1990. Energy contributions of volatile fatty acids from the gastrointestinal tract in various species. Physiol. Rev. 70:567-590.

Bilk, S., K. Huhn, K. U. Honscha, H. Pfannkuche, and G. Gäbel. 2005. Bicarbonate exporting transporters in the ovine ruminal epithelium. J. Comp. Physiol. B 175:365-374. https://doi.org/10.1007/ s00360-005-0493-1.

Connor, E. E., R. W. Li, R. L. Baldwin, and C. Li. 2010. Gene expression in the digestive tissues of ruminants and their relationships with feeding and digestive processes. Animal 4:993-1007. https:// doi.org/10.1017/S1751731109991285.

Dieho, K., A. Bannink, I. A. L. Geurts, J. T. Schonewille, G. Gort, and J. Dijkstra. 2016a. Morphological adaptation of rumen papillae during the dry period and early lactation as affected by rate of increase of concentrate allowance. J. Dairy Sci. 99:2339-2352. https://doi.org/10.3168/jds.2015-9837.

Dieho, K., J. Dijkstra, G. Klop, J. T. Schonewille, and A. Bannink. 2017. The effect of supplemental concentrate fed during the dry period on morphological and functional aspects of rumen adaptation in dairy cattle during the dry period and early lactation. J. Dairy Sci. 100:343-356. https://doi.org/10.3168/jds.2016-11575.

Dieho, K., J. Dijkstra, J. T. Schonewille, and A. Bannink. 2016b. Changes in ruminal volatile fatty acid production and absorption rate during the dry period and early lactation as affected by rate of increase of concentrate allowance. J. Dairy Sci. 99:5370-5384. https://doi.org/10.3168/jds.2015-10819.

Dijkstra, J., H. Boer, J. Van Bruchem, M. Bruining, and S. Tamminga. 1993. Absorption of volatile fatty acids from the rumen of lactating dairy cows as influenced by volatile fatty acid concentration, pH and rumen liquid volume. Br. J. Nutr. 69:385-396. https://doi. org/10.1079/BJN19930041.

Dirksen, G., H. G. Liebich, G. Brosi, H. Hagemeister, and E. Mayer. 1984. Morphologie der Pansenschleimhaut und Fettsäureresorption beim Rind - bedeutende Faktoren für Gesundheit und Leistung. Zentralbl. Veterinarmed. A 31:414-430. https://doi. org/10.1111/j.1439-0442.1984.tb01300.x.

Etschmann, B., A. Suplie, and H. Martens. 2009. Change of ruminal sodium transport in sheep during dietary adaptation. Arch. Anim. Nutr. 63:26-38. https://doi.org/10.1080/17450390802506885.

France, J., and J. Dijkstra. 2005. Volatile fatty acid production. Pages 157-175 in Quantitative aspects of ruminant digestion and metabolism. 2nd ed. J. Dijkstra, J. M. Forbes, and J. France, ed. CABI Publishing, Wallingford, UK.

Graham, C., I. Gatherar, I. Haslam, M. Glanville, and N. L. Simmons. 2007. Expression and localization of monocarboxylate transporters and sodium/proton exchangers in bovine rumen epithelium. Am. J. Physiol. Regul. Integr. Comp. Physiol. 292:R997-R1007. https://doi.org/10.1152/ajpregu.00343.2006.

Gui, H., and Z. Shen. 2016. Concentrate diet modulation of ruminal genes involved in cell proliferation and apoptosis is related to combined effects of short-chain fatty acid and $\mathrm{pH}$ in rumen of goats. J. Dairy Sci. 99:6627-6638. https://doi.org/10.3168/jds.2015-10446.

Hayashi, H., and Y. Yamashita. 2012. Role of N-glycosylation in cell surface expression and protection against proteolysis of the intestinal anion exchanger SLC26A3. Am. J. Physiol. Cell Physiol. 302:C781-C795. https://doi.org/10.1152/ajpcell.00165.2011.

Hickey, K. D., and M. M. Buhr. 2012. Characterization of $\mathrm{Na}^{+} \mathrm{K}^{+}$ ATPase in bovine sperm. Theriogenology 77:1369-1380. https:// doi.org/10.1016/j.theriogenology.2011.10.045.

Kirat, D., J. Masuoka, H. Hayashi, H. Iwano, H. Yokota, H. Taniyama, and S. Kato. 2006. Monocarboxylate transporter 1 (MCT1) plays a direct role in short-chain fatty acids absorption in caprine rumen. J. Physiol. 576:635-647. https://doi.org/10.1113/ jphysiol.2006.115931

Kirat, D., Y. Matsuda, N. Yamashiki, H. Hayashi, and S. Kato. 2007. Expression, cellular localization, and functional role of monocarboxylate transporter 4 (MCT4) in the gastrointestinal tract of ruminants. Gene 391:140-149. https://doi.org/10.1016/j. gene.2006.12.020.

Koho, N., V. Maijala, H. Norberg, M. Nieminen, and A. R. Pösö. 2005. Expression of MCT1, MCT2 and MCT4 in the rumen, small intestine and liver of reindeer (Rangifer tarandus tarandus L.). Comp. Biochem. Physiol. A Mol. Integr. Physiol. 141:29-34. https://doi. org/10.1016/j.cbpb.2005.03.003.

Kristensen, N. B., and D. L. Harmon. 2004. Splanchnic metabolism of volatile fatty acids absorbed from the washed reticulorumen of steers. J. Anim. Sci. 82:2033-2042.

Lam, T. I., P. M. Wise, and M. E. O'Donnell. 2009. Cerebral microvascular endothelial cell $\mathrm{Na}^{+} / \mathrm{H}^{+}$exchange: Evidence for the presence of NHE1 and NHE2 isoforms and regulation by arginine vasopressin. Am. J. Physiol. Cell Physiol. 297:C278-C289. https://doi org/10.1152/ajpcell.00093.2009.

Lane, M. A., and B. W. Jesse. 1997. Effect of volatile fatty acid infusion on development of the rumen epithelium in neonatal sheep. J. Dairy Sci. 80:740-746. https://doi.org/10.3168/jds.S00220302(97)75993-9.

Littell, R. C., P. R. Henry, and C. B. Ammerman. 1998. Statistical analysis of repeated measures data using SAS procedures. J. Anim. Sci. 76:1216-1231.

Littell, R. C., G. A. Milliken, W. W. Stroup, R. D. Wolfinger, and O. Schabenberger. 2006. SAS for Mixed Models, 2nd ed. SAS Institute Inc., Cary, NC.

Melo, L. Q., S. F. Costa, F. Lopes, M. C. Guerreiro, L. E. Armentano, and M. N. Pereira. 2013. Rumen morphometrics and the effect of 
digesta $\mathrm{pH}$ and volume on volatile fatty acid absorption. J. Anim. Sci. 91:1775-1783. https://doi.org/10.2527/jas.2011-4999.

Mentschel, J., R. Leiser, C. Mülling, C. Pfarrer, and R. Claus. 2001. Butyric acid stimulates rumen mucosa development in the calf mainly by a reduction of apoptosis. Arch. Tierernahr. 55:85-102. https://doi.org/10.1080/17450390109386185.

Metzler-Zebeli, B. U., M. Hollmann, S. Sabitzer, L. Podstatzky-Lichtenstein, D. Klein, and Q. Zebeli. 2013. Epithelial response to high-grain diets involves alteration in nutrient transporters and $\mathrm{Na}^{+} / \mathrm{K}^{+}$-ATPase mRNA expression in rumen and colon of goats. J. Anim. Sci. 91:4256-4266. https://doi.org/10.2527/jas.2012-5570.

Minuti, A., A. Palladino, M. J. Khan, S. Alqarni, A. Agrawal, F. Piccioli-Capelli, F. Hidalgo, F. C. Cardoso, E. Trevisi, and J. J. Loor. 2015. Abundance of ruminal bacteria, epithelial gene expression, and systemic biomarkers of metabolism and inflammation are altered during the peripartal period in dairy cows. J. Dairy Sci. 98:8940-8951. https://doi.org/10.3168/jds.2015-9722.

Moll, R., M. Divo, and L. Langbein. 2008. The human keratins: Biology and pathology. Histochem. Cell Biol. 129:705-733. https://doi. org/10.1007/s00418-008-0435-6.

Naeem, A., J. K. Drackley, J. Stamey, and J. J. Loor. 2012. Role of metabolic and cellular proliferation genes in ruminal development in response to enhanced plane of nutrition in neonatal Holstein calves. J. Dairy Sci. 95:1807-1820. https://doi.org/10.3168/ jds.2011-4709.

Oba, M., J. L. Mewis, and Z. Zhining. 2015. Effects of ruminal doses of sucrose, lactose, and corn starch on ruminal fermentation and expression of genes in ruminal epithelial cells. J. Dairy Sci. 98:586594. https://doi.org/10.3168/jds.2014-8697.

Penner, G. B., M. A. Steele, J. R. Aschenbach, and B. W. McBride. 2011. Ruminant nutrition symposium: Molecular adaptation of ruminal epithelia to highly fermentable diets. J. Anim. Sci. 89:11081119. https://doi.org/10.2527/jas.2010-3378.

Penner, G. B., M. Taniguchi, L. L. Guan, K. A. Beauchemin, and M. Oba. 2009. Effect of dietary forage to concentrate ratio on volatile fatty acid absorption and the expression of genes related to volatile fatty acid absorption and metabolism in ruminal tissue. J. Dairy Sci. 92:2767-2781. https://doi.org/10.3168/jds.2008-1716.

Raab, S., R. Leiser, H. Kemmer, and R. Claus. 1998. Effects of energy and purines in the diet on proliferation, differentiation, and apoptosis in the small intestine of the pig. Metabolism 47:1105-1111.

Røjen, B. A., S. B. Poulsen, P. K. Theil, R. A. Fenton, and N. B. Kristensen. 2011. Short communication: Effects of dietary nitrogen concentration on messenger RNA expression and protein abundance of urea transporter-B and aquaporins in ruminal papillae from lactating Holstein cows. J. Dairy Sci. 94:2587-2591. https:// doi.org/10.3168/jds.2010-4073.

Sakata, T., and T. Yajima. 1984. Influence of short chain fatty acids on the epithelial cell division of digestive tract. Q. J. Exp. Physiol. 69:639-648.

Schären, M., G. M. Seyfang, H. Steingass, K. Dieho, J. Dijkstra, L. Hüther, J. Frahm, A. Beineke, D. von Soosten, U. Meyer, G. Breves, and S. Dänicke. 2016. The effects of a ration change from a total mixed ration to pasture on rumen fermentation, volatile fatty acid absorption characteristics, and morphology of dairy cows. J. Dairy Sci. 99:3549-3565. https://doi.org/10.3168/jds.2015-10450.

Schlau, N., L. L. Guan, and M. Oba. 2012. The relationship between rumen acidosis resistance and expression of genes involved in regulation of intracellular $\mathrm{pH}$ and butyrate metabolism of ruminal epithelial cells in steers. J. Dairy Sci. 95:5866-5875. https://doi. org/10.3168/jds.2011-5167.

Schurmann, B. L., M. E. Walpole, P. Górka, J. C. H. Ching, M. E. Loewen, and G. B. Penner. 2014. Short-term adaptation of the ruminal epithelium involves abrupt changes in sodium and short-chain fatty acid transport. Am. J. Physiol. Regul. Integr. Comp. Physiol. 307:R802-R816. https://doi.org/10.1152/ ajpregu.00035.2014.

Sehested, J., J. B. Andersen, O. Aaes, N. B. Kristensen, L. Diernæs, P. D. Møller, and E. Skadhauge. 2000. Feed-induced changes in the transport of butyrate, sodium and chloride ions across the isolated bovine rumen epithelium. Acta Agric. Scand. Anim. Sci. 50:47-55. https://doi.org/10.1080/090647000423924.

Simmons, N. L., A. S. Chaudhry, C. Graham, E. S. Scriven, A. Thistlethwaite, C. P. Smith, and G. S. Stewart. 2009. Dietary regulation of ruminal bovine UT-B urea transporter expression and localization. J. Anim. Sci. 87:3288-3299. https://doi.org/10.2527/ jas.2008-1710.

Steele, M. A., L. Dionissopoulos, O. AlZahal, J. Doelman, and B. W. McBride. 2012. Rumen epithelial adaptation to ruminal acidosis in lactating cattle involves the coordinated expression of insulin-like growth factor-binding proteins and a cholesterolgenic enzyme. J. Dairy Sci. 95:318-327. https://doi.org/10.3168/jds.2011-4465.

Steele, M. A., C. Schiestel, O. AlZahal, L. Dionissopoulos, A. H. Laarman, J. C. Matthews, and B. W. McBride. 2015. The periparturient period is associated with structural and transcriptomic adaptations of rumen papillae in dairy cattle. J. Dairy Sci. 98:2583-2595. https://doi.org/10.3168/jds.2014-8640.

Steele, M. A., G. Vandervoort, O. AlZahal, S. E. Hook, J. C. Matthews, and B. W. McBride. 2011. Rumen epithelial adaptation to high-grain diets involves the coordinated regulation of genes involved in cholesterol homeostasis. Physiol. Genomics 43:308-316. https://doi.org/10.1152/physiolgenomics.00117.2010.

Storm, A. C., M. D. Hanigan, and N. B. Kristensen. 2011. Effects of ruminal ammonia and butyrate concentrations on reticuloruminal epithelial blood flow and volatile fatty acid absorption kinetics under washed reticulorumen conditions in lactating dairy cows. J. Dairy Sci. 94:3980-3994. https://doi.org/10.3168/jds.2010-4091.

Sutton, J. D., M. S. Dhanoa, S. V. Morant, J. France, D. J. Napper, and E. Schuller. 2003. Rates of production of acetate, propionate, and butyrate in the rumen of lactating dairy cows given normal and low-roughage diets. J. Dairy Sci. 86:3620-3633. https://doi. org/10.3168/jds.S0022-0302(03)73968-X.

Tamminga, S., W. M. Van Straalen, A. P. J. Subnel, R. G. M. Meijer, A. Steg, C. J. G. Wever, and M. C. Blok. 1994. The Dutch protein evaluation system: the DVE/OEB-system. Livest. Prod. Sci. 40:139-155. https://doi.org/10.1016/0301-6226(94)90043-4.

Van Es, A. J. H. 1978. Feed evaluation for ruminants. I. The systems in use from May 1977 onwards in The Netherlands. Livest. Prod. Sci. 5:331-345. https://doi.org/10.1016/0301-6226(78)90029-5.

Von Engelhardt, W., and J. R. Hales. 1977. Partition of capillary blood flow in rumen, reticulum, and omasum of sheep. Am. J. Physiol. 232:E53-E56.

Yan, L., B. Zhang, and Z. Shen. 2014. Dietary modulation of the expression of genes involved in short-chain fatty acid absorption in the rumen epithelium is related to short-chain fatty acid concentration and $\mathrm{pH}$ in the rumen of goats. J. Dairy Sci. 97:5668-5675. https://doi.org/10.3168/jds.2013-7807.

Yang, W., Z. Shen, and H. Martens. 2012. An energy-rich diet enhances expression of $\mathrm{Na}^{+} / \mathrm{H}^{+}$exchanger isoform 1 and 3 messenger RNA in rumen epithelium of goat. J. Anim. Sci. 90:307-317. https://doi.org/10.2527/jas.2011-3854.

Zachos, N. C., M. Tse, and M. Donowitz. 2005. Molecular physiology of intestinal $\mathrm{Na}^{+} / \mathrm{H}^{+}$exchange. Annu. Rev. Physiol. 67:411-443. https://doi.org/10.1146/annurev.physiol.67.031103.153004. 